\title{
Modelling larval dispersal and settlement of the reef-building polychaete Sabellaria alveolata: Role of hydroclimatic processes on the sustainability of biogenic reefs
}

\author{
Sakina-Dorothée Ayata ${ }^{a, b, ~}{ }^{*}$, Céline Ellien ${ }^{c}$, Franck Dumas $^{d}$, Stanislas Dubois ${ }^{d}$ and Éric \\ Thiébaut ${ }^{\mathrm{a}, \mathrm{b}}$
}

\footnotetext{
a Université Pierre \& Marie Curie-Paris 06, Station Biologique de Roscoff, Laboratoire 'Adaptation et diversité en milieu marin', BP 74, F-29682 Roscoff cedex, France

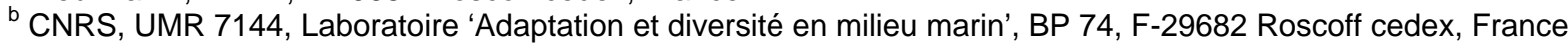

c Muséum National d'Histoire Naturelle, Département 'Milieux et Peuplements Aquatiques', UMR 5178, 61 rue Buffon, CP 53, F-75231 Paris cedex 05, France

d Ifremer, Département 'Dynamiques de l'Environnement Côtier', BP 70, F-29280 Plouzané, France
}

\begin{abstract}
*: Corresponding author: Ayata S.-D., Tel.: +33 2982925 31; fax: +33 2982923 24, email address : sakina.ayata@normalesup.org
\end{abstract}

\begin{abstract}
:
The honeycomb worm Sabellaria alveolata forms biogenic reefs which constitute diversity hotspots on tidal flats. The largest known reefs in Europe, located in the Bay of Mont-Saint-Michel (English Channel), are suffering increasing anthropogenic disturbances which raise the question of their sustainability. As the ability to recover depends partly on the recolonization of damaged reefs by larval supply, evaluating larval dispersal and the connectivity between distant reefs is a major challenge for their conservation. In the present study, we used a 3D biophysical model to simulate larval dispersal under realistic hydroclimatic conditions and estimate larval retention and exchanges among the two reefs of different sizes within the bay. The model takes into account fine-scale hydrodynamic circulation $\left(800 \times 800 \mathrm{~m}^{2}\right)$, advection-diffusion larval transport, and gregarious settlement behaviour. According to the field data, larval dispersal was simulated for a minimal planktonic larval duration ranging from 4 to 8 weeks and the larval mortality was set to $0.09 \mathrm{~d}^{-1}$. The results highlighted the role played by a coastal eddy on larval retention within the bay, as suggested by previous in situ observations. Very different dispersal patterns were revealed depending on the spawning reef location, although the two reefs were located only $15 \mathrm{~km}$ apart. The settlement success of the larvae released from the smallest reef was mainly related to tidal conditions at spawning, with the highest settlement success for releases at neap tide. The settlement success of the larvae from the biggest reef was more dependent on meteorological conditions: favourable W and SW winds may promote a ten-fold increase in settlement success. Strong year-to-year variability was observed in settlers' numbers, with favourable environmental windows not always coinciding with the main reproductive periods of Sabellaria. Settlement kinetics indicated that the ability to delay metamorphosis could significantly improve the settlement success. Although bidirectional exchanges occurred between the two reefs, the highest settlers' numbers originated from the biggest reef because of its stronger reproductive output. Because of the recent decline of this reef due to increasing anthropogenic disturbances larval supply in the bay may not be sufficient enough to ensure the sustainability of the remarkable habitat formed by Sabellaria alveolata reefs.
\end{abstract}

Keywords: Sabellaria alveolata; Biogenic reefs; Connectivity; Larval transport; Larval settlement; Modelling; English Channel; Bay of Mont-Saint-Michel 


\section{Introduction}

In coastal temperate regions, reef-building organisms including polychaetes (e.g. sabellariids, serpulids) and bivalves (e.g. mytilids, ostreids) act as ecosystem engineers by physically creating, modifying and maintaining habitats (Jones et al., 1997). By adding micro-scale topographic complexity to the environment, biogenic reefs offer shelters for a large number of marine species and form local hotspots of biodiversity. Although the direct positive effects of the structures built by ecosystem engineers can last longer than the lifetime of the engineer itself, sheltered species diversity tends to decline with the degradation of the reef (Hastings et al., 2007). Thus, the protection of such habitats constitute a major challenge for the biodiversity conservation as they are increasingly threatened by both climate changes and anthropogenic disturbances, such as pollution, overfishing of reef-associated species, or physical degradation of the reefs (Vorberg, 1995; Dubois et al., 2002, 2006). To inventory, preserve and restore the biogenic reefs, action plans have been recently proposed like the European Habitats Directive ("Council Directive 92/43/EEC on the Conservation of Natural Habitats and of Wild Fauna and Flora") whose Annex I lists the biogenic reefs of open seas and tidal areas among the "natural habitat types of community interest whose conservation requires the designation of special areas of conservation" (Holt et al., 1998). Nevertheless, more research is generally needed to evaluate the extinction risk of those reefs and to propose specific protection management.

Like most marine benthic invertebrates, reef-building organisms exhibit a bentho-pelagic life cycle including a planktonic larval stage of development and two sedentary benthic juvenile and adult stages. For those organisms, successful settlement requires that larvae reach a suitable habitat within a competency period at the end of larval development. It depends on numerous factors involved in larval dispersal and results either from the local retention of larvae or from the connectivity among spatially 
isolated populations (Caley et al., 1996). Since they drive planktonic larvae, oceanographic processes (e.g. tidal residual currents, wind-induced currents, upwellings, river plumes or gyres) and their variability on time and space scales relevant to the life history of the organism greatly control larval dispersal. On the other hand, dispersal abilities also depend on the interactions between hydrodynamics and biological properties, like spawning period, larval stage duration or larval behaviour. Larval dispersal and connectivity (i.e. the exchange of individuals among geographically isolated marine populations) play then a major role in marine population and metapopulation dynamics in the face of habitat fragmentation (Kinlan et al., 2005; Hastings and Botsford, 2006). A marine metapopulation is defined as a system of discrete local populations which are strongly dependent upon local demogaphic processes but are also influenced by external supply for population replenishment (Kritzer and Sale, 2003). The metapopulation concept, which has been dramatically developed in marine ecology during the last decade, has become crucial for the maintenance of local adult populations, their ability to recover from natural and anthropogenic disturbances or the implementation of marine conservation and management strategies (Botsford et al. 2001; Hastings and Botsford, 2006). Spatially explicit models highlight the importance of the size and location of discrete local populations and of the spatial scales of dispersal and connectivity in the metapopulation dynamics (Botsford et al. 1994; Gaines et al. 2003; Gerber et al. 2003).

The honeycomb worm Sabellaria alveolata is the most common reef-building polychaete along the NE Atlantic coasts, living in the intertidal fringe from the Solway Firth (West Scotland) to the South of the Moroccan coasts (Cunningham et al., 1984). Along the European coasts, the largest reef structures are located in the Bay of Mont-Saint-Michel (English Channel) where they form irregularly shaped, patchy banks that may exceed one meter high and cover a surface of several hundreds of hectares. The two main formations reported within the bay (i.e. Sainte-Anne reef and Champeaux reef) provide a complex habitat 
for macrofauna and exhibit high levels of biodiversity that contrast with the surrounding soft-bottom environments (Dubois et al., 2002). If these biodiversity hotspots are a highly dynamic habitat subject to numerous natural perturbations (e.g. storms), they are also increasingly threatened by direct and indirect anthropogenic disturbances including the colonization by mussels and oysters from local aquaculture, the development of ephemeral green algae in response to eutrophication or the physical degradation of the reef through trampling and shellfish farming (Dubois et al., 2002, 2006). These disturbances may cause significant damages to the reef structure and a reduction in density of new recruits has already been reported (Dubois et al., 2006).

According to these damages, the long-term persistence of Sabellaria alveolata reefs in the Bay of Mont-Saint-Michel is questionable and would partly depend on sufficient larval supply during the worm life span, which varies between 4 and 5 years and can more rarely reach 8-10 years (Wilson, 1971). Larval supply may be all the more important since large year-to-year variations in the recruitment of Sabellaria alveolata were commonly reported (Wilson, 1971; Gruet, 1986). Indeed, as a species with a long larval life span (Wilson, 1968b; Cazaux, 1970; Dubois et al., 2007), one speculative possibility to explain recruitment failure would be the lack of larval supply due to circulation conditions flushing larvae away from the reefs (Holt et al., 1998). Conversely, several processes have been proposed to explain local successful settlement and reduced larval losses in this species. First, competent Sabellaria alveolata larvae - i.e. larvae that have acquired the ability to settle - exhibit an active habitat selection and are able to delay metamorphosis (Wilson, 1968a; Pawlick, 1988). Second, in the Bay of Mont-Saint-Michel, Sabellaria alveolata presents an extended reproductive period with a semi-continuous spawning from April to October (Dubois, 2003; Dubois et al., 2007). This long period of larval occurrence in the water column increases the probability that some larvae match favourable environmental conditions and 
successfully settle. Third, preliminary field observations on larval distribution carried out within the bay in July 2002 suggested that the tidal residual circulation, especially the occurrence of eddy structures could limit larval horizontal transport and contribute to larval retention for a few weeks (Dubois et al., 2007).

While understanding factors that control larval dispersal and larval supply to benthic populations is a fundamental issue in conservation biology, quantifying empirically these parameters and their spatiotemporal variations remains extremely difficult. Nevertheless, recent methodological developments including molecular ecology, geochemical fingerprinting and hydrodynamic modelling provide new powerful tools to study larval dispersal (see the review by Levin, 2006). Numerical simulations constitute a quantitative approach to better understand the role of highly changeable hydrodynamics and biological factors on larval dispersal, and estimate dispersal distance and potential origin of larval supply. Although biophysical models vary a lot in terms of spatial scales andcomplexity, two main types of model are commonly used to simulate larval dispersal in marine organisms: (i) Eulerian models that solve an advection-diffusion equation and provide the spatial and temporal evolution of larval concentrations at each mesh point and (ii) Lagrangian models (also called individual-based models or IBM) that compute individual particle pathways. The latter have been widely used during the last years to follow the trajectories of a large number of larval particles with specific parameters (e.g. larval growth, larval behaviour) in order to simulate the dispersal of different marine invertebrates and fishes (see review by Miller, 2007, and references therein). Conversely, advection-diffusion models allow to save computing time when larval transport is simulated for a long period of time and when no individual specificities are considered, usually because of limited knowledge of biological parameters such as growth conditions or behaviour response to the environment. Although a comprehensive larval dispersal model should account 
for 3D flow regimes, individual larval locomotion and some demographic parameters, dispersal has been successfully modelled as an advection-diffusion process for several invertebrates like polychaetes (Jolly et al., in press), bivalves (Gilg and Hilbish, 2003), echinoderms (Dunstan and Bax, 2007), and corals (Treml et al., 2008). Here, we propose to explore realistic potential dispersal of Sabellaria alveolata larvae in an Eulerian framework using a 3-dimensional hydrodynamic model of the Bay of Mont-Saint-Michel which predicts tidally and wind-induced currents, and drives an advection-diffusion larval transport model accounting also for larval mortality and settlement. In this context, the aims of our study are (1) to assess the role of hydrodynamic variations on the variability of larval dispersal and larval settlement within the bay, (2) to estimate larval exchanges between the two isolated reefs of the bay and (3) to evaluate the influence of spawning date and delayed metamorphosis on settlement kinetics. These results will be discussed in terms of Sabellaria alveolata reefs sustainability in the Bay of Mont-Saint-Michel and the designation of conservation strategies. Is the self-replenishment sufficient to ensure the long-term persistence of reefs within the bay? What is the relative importance of both reefs on regional larval supply? Should protection measures privilege one reef?

\section{Material and Methods}

\subsection{Study area}

The Bay of Mont-Saint-Michel forms a coastal embayment in the southeast of the Gulf of SaintMalo (western English Channel) and covers an area of about $500 \mathrm{~km}^{2}$ between the Pointe du Grouin and Granville, including $240 \mathrm{~km}^{2}$ of tidal flats (Fig. 1). It is a macrotidal system with a tidal range reaching 16 $\mathrm{m}$ during spring tide and maximal instantaneous tidal currents varying between 0.5 and $0.8 \mathrm{~m} \mathrm{~s}^{-1}$ (Orbi 
and Salomon, 1988). Freshwater inputs coming from 3 small rivers (i.e. the Sée, the Sélune and the Couesnon) do not exceed $25 \mathrm{~m}^{3} \mathrm{~s}^{-1}$ and have insignificant effect on the circulation. The water column is well-mixed in most of the bay all along the year because the strong tidal currents cause intense vertical mixing (Pingree et al, 1985). In the Gulf of Saint-Malo, residual circulation depends mainly on the tides and is characterized by the occurrence of several cyclonic and anticyclonic gyres (Salomon and Breton, 1993; Salomon et al., 1996). They result either of the tidal motion rotating around islands as around the Channel Islands (e.g. Jersey and Chausey Islands) or of cape-effects as off Cancale. Those gyres are perennial, although the gyre off Cancale can be sporadically altered under particular wind conditions (i.e. constant southern wind exceeding $8 \mathrm{~m} \mathrm{~s}^{-1}$ ) (Salomon and Breton, 1993).

Two main Sabellaria alveolata reefs of different sizes are present in the intertidal zone of the Bay of Mont-Saint-Michel: (1) the largest one in the central part of the bay (i.e. Sainte-Anne reef, $48^{\circ} 35^{\prime} \mathrm{N}-$ $01^{\circ} 40^{\prime} \mathrm{W}$ ) with a projected 3D-surface area of $2.23 \mathrm{~km}^{2}$ and (2) the smallest one in the East of the bay (i.e. Champeaux reef, $48^{\circ} 44^{\prime} \mathrm{N}-01^{\circ} 33^{\prime} \mathrm{W}$ ) with a projected 3D-surface area of $0.29 \mathrm{~km}^{2}$. Sainte-Anne reef is located adjacent to extensive culture structures for mussels and oysters. The reefs form a mosaic of three morphological stages representative of the reef dynamics: ball-shaped structures, platforms, and degraded reef (Gruet, 1982). Each stage corresponds to different infaunal species assemblages and to different demographic structures of the S. alveolata population (Dubois et al., 2002).

\subsection{The hydrodynamic model}

The circulation in the Gulf of Saint-Malo is simulated using a three-dimensional hydrodynamic model, i.e. the Model for Applications at Regional Scale (MARS) (Lazure and Dumas, 2008), which is a primitive equation, finite-difference model in sigma coordinates. It solves the Navier-Stokes equations 
under the conventional Boussinesq and hydrostatic assumptions (see Appendix 1 for the detailed equations of the hydrodynamic model). One original aspect of the model is that the barotropic mode (free surface wave propagation) is semi-implicitly solved using an Alternate Direction Implicit scheme; it allows a coupling with the baroclinic mode (internal motion) using identical time discretization. Grid cells emerging at low tide have the ability to dry and wet in a mass-conservative way (Plus et al, 2009). This model has been shown to reproduce accurately both hydrodynamic and hydrological structures, such as instantaneous tidal currents or tidal elevation on the Bay of Biscay continental shelf (Lazure and Dumas, 2008) or in a very shallow coastal embayment, the Arcachon Bay (Plus et al., 2009). It has been qualitatively evaluated in the Bay of Mont-Saint-Michel by the comparison with the observed hydrodynamic structures, such as the gyre off Cancale, evidenced by neutrally buoyant floats (Orbi and Salomon, 1988), measurements of radioactive tracers (Bailly du Bois and Dumas, 2005), or direct current measurements (Sentchev et al, 2009). The MARS 3D model was extensively used to study transport of dissolved and particulate matter on the NW European continental shelves (Lazure and Jegou, 1998; Delhez et al., 2004 ; Allain et al., 2007; Xie et al., 2007; Lazure and Dumas, 2008). In the present study, the model domain extends from $48^{\circ} 49^{\prime} 00^{\prime}$ ' $\mathrm{N}$ to $49^{\circ} 34^{\prime} 00^{\prime}$ ' $\mathrm{N}$ in latitude and from $02^{\circ} 27^{\prime} 34^{\prime \prime} \mathrm{W}$ to $01^{\circ} 23^{\prime} 42^{\prime \prime} \mathrm{W}$ in longitude according to the well-known limits of hydrodynamic residual structures in the English Channel (Salomon and Breton, 1993). Those model boundaries are also sufficient for the potential maximal distance reached by the larvae during their dispersion. The horizontal grid is regular with a mesh size of $800 \mathrm{~m}$. Ten sigma levels (i.e. terrain-following curvilinear coordinates) are used with relative heights from the bottom to the surface of : $15 \%, 15 \%, 15 \%, 15 \%, 12.5 \%, 10 \%$, $7.5 \%, 4.5 \%, 3.5 \%$, and $2 \%$; spacing is much closer near the surface to better resolve the surface layers. The coastline was provided by the "Service Hydrographique et Océanographique de la Marine" (SHOM) 
(map resolution of 25/1000). The model bathymetry was estimated from: (1) LIDAR data with a 5-meter resolution for the intertidal flat of the bay (see Populus et al, 2004), (2) IFREMER hydrographic data from mono-beam sounder with one measurement every $4 \mathrm{~m}$ along transects located every $200 \mathrm{~m}$ in the subtidal area of the bay, and (3) SHOM numerical bathymetry maps for the rest of the gulf. The open boundary conditions (i.e. free surface elevation) were obtained from two larger nested barotropic models (one for the NW European continental shelf extending from Portugal to Iceland, with a horizontal resolution of $5.6 \mathrm{~km}$, and one for the English Channel, with a horizontal resolution of $3 \mathrm{~km}$ ) which took into account the 8 main tidal waves $\left(\mathrm{M}_{2}, \mathrm{~S}_{2}, \mathrm{~N}_{2}, \mathrm{~K}_{2}, \mathrm{O}_{1}, \mathrm{~K}_{1}, \mathrm{P}_{1}\right.$ and $\left.\mathrm{Q}_{1}\right)$. Tidal constituents along the open boundary of the largest model were extracted from the Schwiderski atlas (Schwiderski, 1983). Here, for the 3 models, surface wind stress and pressure were provided by the meteorological ARPEGE model from MétéoFrance. This regional model has a spatial resolution of $0.5^{\circ}$ in longitude and latitude and gives 4 analysed wind and pressure fields per day. Given the flat surrounding topography, orographic channelling potentially caused by local winds are considered negligible and the role played by local winds on the circulation of the bay is not taken into account. Simulated wind stress was highly correlated to wind data observed at different weather stations along the coasts of the Gulf of Saint-Malo (data not shown). River discharges in the Bay of Mont-Saint-Michel are considered negligible (mean outflow of 7 $\mathrm{m}^{3} \mathrm{~s}^{-1}$ ) and are thus not taken into account in the model.

\subsection{The larval transport model}

To simulate the transport of Sabellaria alveolata larvae, an Eulerian approach was chosen instead of a Lagrangian approach because of the lack of enough data to parameterize individual larval behaviour and development in response to environmental parameters. The larval transport is calculated by solving 
the following advection-diffusion-mortality equation in a mass conservative form using the 3D current velocity fields calculated by the hydrodynamic model:

$$
\frac{\partial D C}{\partial t}+\frac{\partial D\left(u C-k x \frac{\partial C}{\partial x}\right)}{\partial x}+\frac{\partial D\left(v C-k y \frac{\partial C}{\partial y}\right)}{\partial y} \frac{\partial D\left(w * C-\frac{k z}{D^{2}} \frac{\partial C}{\partial \sigma}\right)}{\partial \sigma} \frac{\partial r}{\partial t} \frac{\partial s}{\partial t}
$$

with $C$, the larval concentration per grid cell, $D$, the water column height, $t$, the time, $x$ and $y$, the horizontal coordinates, $\sigma$, the vertical sigma coordinate, $u$, the zonal velocity, $v$, the meridional velocity, $w^{*}$, the vertical velocity in the sigma coordinate framework, $k_{x}$ and $k_{y}$, the horizontal eddy diffusivity coefficients, $k_{z}$, the vertical eddy diffusivity, $r$, the larval release term (see section 2.4 ), $\mu$, the constant mortality rate, and $s$, the larval settlement term (see section 2.5).

Coastal boundaries are perfectly reflecting while the open sea boundaries are absorbing: a larva that is transported outside these boundaries is lost and can not return in the model domain. Even if preliminary observations suggested that the vertical distribution of Sabellaria alveolata larvae in the Bay of Mont-Saint-Michel may vary over short-term periods (Dubois, 2003; Dubois et al., 2007), field observations are still lacking to describe analytically the vertical distribution of the larvae and to parametrize it in the present model in a realistic manner. Larvae are thus considered in a first approximation as passive, i.e. not able to control their vertical position. As no falling or swimming velocity is taken into account in the transport equation, simulated larval densities are homogeneous along the vertical axis (data not shown).

Although larval mortality is an important demographic parameter in the understanding of the role of the larval phase on benthic populations' dynamics (i.e. fate of larval supply, connectivity between distant populations) (Cowen et al., 2000; Ellien et al., 2004), accurate estimations of larval mortality and its variability are generally lacking for most invertebrates. Here, the mortality rate was fixed at $0.09 \mathrm{~d}^{-1}$ 
following an 8-months temporal survey of Sabellaria larvae abundances in the bay (Dubois et al., 2007). It was supposed constant in time and space. A preliminary sensitivity study to this parameter with rates ranging from 0 to $0.36 \mathrm{~d}^{-1}$ indicated that the final number of settlers was inversely proportional to the mortality rate but that its variation did not alter larval dispersal patterns and settlement dynamics.

\subsection{Larval release}

Sabellaria alveolata is a gonochoric species with a sex-ratio of 1:1 (Dubois, 2003). It is an iteroparous breeder whose individuals become mature after one year. Within the bay, the spawning occurs throughout most of the year (from April to October) with two main periods in early May to June and in September (Dubois et al., 2007). Ovigerous females are reported throughout the year and represent up to $65 \%$ of the female populations (15\% on average) (Dubois, 2003). If the fecundity is highly variable among females and seasons, a mean value of 100000 ovocytes per female has been calculated (Dubois, 2003). Despite an external fertilization, the aggregative distribution of adults suggests a high fertilization success, so a fertilization success of $80 \%$ was assumed (Eckman, 1996).

Spawning was simulated within the bay at the locations of the two reefs that correspond to 4 grid cells for the Sainte-Anne reef and to 1 grid cell for the Champeaux reef. According to field observations (Dubois et al., 2002; Dubois, 2003), the size of the adult population for both reefs was estimated from (1) the surface of each reef, (2) the proportions of the different reef structures, and (3) the mean density of adult worms for each type of reef structure (Table 1). The number of larvae released by each reef during a spawning event was calculated from (1) the adult population size, (2) a 1:1 sex ratio, (3) the mean proportion of ovigerous females within the population, (4) the mean fecundity and (5) a $80 \%$ fertilization rate (Table 1). For each spawning event, a total of $2.52 \times 10^{14}$ and $4.8 \times 10^{13}$ larvae was then released from 
the Sainte-Anne and Champeaux reefs, respectively.

Dubois et al. (2007) suggested that the seasonal reproduction of $S$. alveolata may be related to spring temperature increase and to spring and autumn phytoplanktonic blooms. By contrast, the numerous exogenous and endogenous cues that may control the short-term rhythmicity of spawning events at the population level remain unknown while it has been reported that spawning of intertidal polychaetes may occur at the incoming tide and during a few successive days (Bentley and Pacey, 1992; Olive, 1992). On the other hand, for different marine invertebrates like mussels or sea urchins, the occurrence in the water column of specific chemical signals (e.g. phytoplankton blooms, sperm from conspecifics) may enhance the synchrony of spawning and trigger mass spawning (Starr et al., 1990). In most simulations, larvae are then released instantaneously at high tide in the lowest grid cells located above the reefs as follows in the sigma coordinate framework $(x, y, \sigma)$ :

$$
\begin{aligned}
& \frac{\partial r(x, y, \sigma, t)}{\partial t}=\frac{N_{0}}{V_{x y \sigma(1)}} \quad \text { when } t=t_{0} \\
& \{x, y\} \in\{\text { reef coordinates }\} \\
& \sigma=\sigma(1) \\
& D(x, y)>0.5 \\
& \frac{\partial r(x, y, \sigma, t)}{\partial t}=0
\end{aligned}
$$

with $r$, the larval release function, $N_{0}$, the total number of released larvae, $t_{0}$, the time at high tide and, $\mathrm{V}_{\mathrm{xy}}$ $\sigma(1)$, the volume of the lower cell of coordinates $(x, y, \sigma(1))$.

The volume of the lower cell of coordinates $(x, y, \sigma(1))$ is given by:

$$
V_{x y \sigma(1)}=S(x, y) h_{x y \sigma(1)} D(x, y)
$$

with $S(x, y)$, the surface of a cell equal to $0.16 \mathrm{~km}^{2}, h_{x y s(I)}$, the relative height of the lowest sigma layer 
equal to 0.15 and, $D(x, y)$, the total water column height.

To evaluate the impact of this simple formulation of spawning, 3 other formulations of larval release are considered: a uniform continuous spawning of $4 \mathrm{~h}$ over one tidal cycle, a symmetric semi-continuous spawning over 3 tidal cycles and a symmetric semi-continuous spawning over 5 tidal cycles. The detailed equations for these larval release formulations are given in Appendix 2.

\subsection{Larval settlement}

From laboratory cultures, Wilson $(1968 b, 1970)$ reported large variations in Sabellaria alveolata larval life span, from 6 weeks to 11 months, partly in relation to natural variability among individuals and culture conditions (food, temperature). Conversely, Dubois et al. (2007) estimated from in situ larval sampling in the Bay of Mont-Saint-Michel that planktonic lifetime ranged between 4 and 10 weeks. On the other hand, competent larvae positively respond to chemical cues produced by the congeneric adult and juvenile tubes and could delay metamorphosis if proper environment for settlement is not encountered (Wilson, 1968a; Pawlick, 1988). In the present study, we considered that when the larvae become competent, they can delay their settlement during 4 more weeks. The age at competence, i.e. the minimal planktonic larval duration (PLD), was set at 6 weeks, leading to a maximal PLD of 10 weeks. To assess the consequences on settlement of PLD variations related to seasonal variations in environmental conditions (e.g. temperature, food availability), 9 values of minimal PLD ranging from 4 to 8 weeks were also tested.

Chemosensory responses of larvae to specific cues associated with the bottom are likely (1) to modify larval behaviour in the water column and favour larval concentration near the bottom, and (2) to increase the probability of substratum acceptance (Eckman, 1996). As the behaviour of Sabellaria 
competent larvae and the maximal perception distance of the chemical cues remain unknown, larval settlement was simulated according to the following criteria: (1) larvae can settle from the beginning of the competence period (i.e. minimal PLD) and delay their metamorphosis during 4 weeks (i.e. maximal PLD = minimal PLD + 4 weeks); (2) larval settlement was restricted to the grid cells above the adult reefs and within the last $3 \mathrm{~m}$ above the bottom; (3) $50 \%$ of the competent larvae present within the last $3 \mathrm{~m}$ above an adult reef settled. The detailed equation of the larval settlement term is given below:

$$
\frac{\partial s(x, y, \sigma, t)}{\partial t}=r s p \sigma C(x, y, \sigma) \quad \text { when } \quad t \min P L D \leq t<t \min P L D+t \text { delay }
$$

$$
\begin{aligned}
& \{x, y\} \in \mid \text { reef coordinates } \mid \\
& \sigma<\sigma_{\text {perception }}=\frac{z_{\text {perception }}+H}{\zeta+H} \\
& \frac{\partial s(x, y, \sigma, t)}{\partial t}=0 \\
& \text { otherwise }
\end{aligned}
$$

with $s$, the larval settlement function, $r_{s}$, the settlement rate fixed at $50 \%, p_{\sigma}$ the proportion of the sigma layers in which larvae can detect adult habitat, $t_{\min P L D}$, the age at competence, $t_{\text {delay }}$, the maximal metamorphosis delay fixed at 4 weeks, $z_{\text {perception }}$, the maximal perception distance fixed at 3 meters, $H$, the absolute value of bottom position, $\zeta$, the sea surface elevation.

For any sigma layer, the proportion of the sigma layer in which larvae can detect adult habitat is defined as:

$$
\begin{array}{lll}
p_{\sigma}=1 & \text { when } \sigma<\sigma_{\text {inf }} \\
p_{\sigma}=\sigma_{\text {perception }}-\sigma_{\text {inf }} & \text { when } \sigma=\sigma_{\text {inf }} \\
p_{\sigma}=0 & \text { when } \sigma>\sigma_{\text {inf }}
\end{array}
$$


where $\sigma_{\text {inf }}$ is the higher sigma level above the maximal perception distance $\mathrm{z}$ perception defined by:

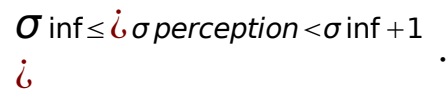

\subsection{Simulations}

For both reefs, several sets of larval dispersal simulations were performed to investigate the influences of tides and winds at different temporal scales over the whole Sabellaria alveolata spawning period (Table 2). First, 4 types of larval release (instantaneous spawning, uniform continuous spawning during 1 tidal cycle, symmetric semi-continuous spawning during 3 tidal cycles, and symmetric semicontinuous spawning during 5 tidal cycles) were tested during average tide conditions in June 2002 and with no wind forcing. Second, the influence of the lunar tidal cycle was determined following instantaneous spawning events in different tidal conditions and with no wind forcing between March and October 2002: 16 spawning events in average tide, 7 spawning events in neap tide, and 7 spawning events in spring tide. Third, to assess the role of wind stress, the 16 previous simulations performed for a spawning in average tide were realised again under a real wind forcing. Finally, to estimate the influence of inter-annual variability in the meteorological conditions, larval dispersal was simulated between 2000 and 2004, for 7 spawning events in average tide each year, under a real wind forcing. A sensitivity analysis on the age at competence was also performed with minimal PLD ranging from 4 to 8 weeks for an instantaneous spawning release in average tide condition and with no wind forcing.

For each simulation, the following parameters were calculated at the end of the dispersal phase:

(1) the density of autochthonous and allochthonous settlers for each reef;

(2) the retention rate within each reef (i.e. ratio between the number of autochthonous settlers in a reef 
and the total number of larvae released from this reef);

(3) the colonization rate of each reef (i.e. ratio between the number of allochthonous settlers in the colonized reef and the total number of larvae emitted from the colonizing reef);

(4) the total settlement rate from each reef (i.e. ratio between the total number settlers from a reef and the total number of larvae emitted from this reef);

(5) the allochthonous settlement ratio for each reef (i.e. ratio between the number of allochthonous and autochthonous settlers within a reef).

\section{Results}

\subsection{Residual circulation in the Gulf of Saint-Malo}

Without wind forcing, the tidal residual circulation of the Gulf of Saint-Malo was characterized by large spatial variations in current velocity, from less than $2 \mathrm{~cm} \mathrm{~s}^{-1}$ to more than $20 \mathrm{~cm} \mathrm{~s}^{-1}$. It exhibited also remarkable meso-scale features including an alongshore current (eastwards off the Brittany then northwards off the Normandy, velocity from 5 to $10 \mathrm{~cm} \mathrm{~s}^{-1}$ ) and several cyclonic (anticlockwise) and anticyclonic (clockwise) gyres (Fig. 2A). Cyclonic gyres were formed around the Jersey Island and Les Minquiers Archipelago while an anticyclonic cape gyre of $\sim 15 \mathrm{~km}$ in diameter occurred off Cancale. The areas with the slowest currents $\left(<2.5 \mathrm{~cm} \mathrm{~s}^{-1}\right)$ were located in the South of Granville and in the North of

Chausey Island. Maximal currents $\left(>20 \mathrm{~cm} \mathrm{~s}^{-1}\right)$ were locally reported off different capes and around Les Minquiers.

Wind forcing could partly alter this circulation scheme according to its direction and velocity. As an example, Figs. 2B and 2C illustrate the effect of a uniform moderate wind stress (velocity of $11 \mathrm{~m} \mathrm{~s}^{-1}$ ) from SW and NE on the residual circulation, these compass directions corresponding to dominant winds 
in the bay. Under a SW wind forcing, the spatial extent of the gyre off Cancale was then reduced to the western half of the Bay of Mont-Saint-Michel (Fig. 2B). The alongshore currents off Saint Malo and the Normandy coasts were accelerated and low currents $\left(<2.5 \mathrm{~cm} \mathrm{~s}^{-1}\right)$ were reported in the South of the bay. Under a NE wind forcing, the gyre off Cancale was extended to the entire Bay of Mont-Saint-Michel (30 $\mathrm{km}$ of diameter) (Fig. 2C). Residual currents within the gyre were strengthened ( $>10 \mathrm{~cm} \mathrm{~s}^{-1}$ in the south) while the northwards current along the Normandy coasts was slightly decreased.

\subsection{Influence of tides on larval dispersal and settlement}

\subsubsection{General pattern of larval dispersal}

Without wind forcing, dispersal simulations of larvae released instantaneously at high tide and in average tide conditions showed that most larvae were progressively retained in the gyre off Cancale (Fig. 3). The larval cohort never extended further than $20 \mathrm{~km}$ westward from the Pointe du Grouin but could spread northwards along the Cotentin coast.

However, dispersal pattems differed according to the emission reef (Fig. 3). Following a spawning event from Sainte-Anne, larvae were first transported westwards (Fig. 3A) and were then trapped in the gyre off Cancale (Fig. 3B). When the larvae become competent at 6 weeks, the highest larval concentrations (i.e. $>12,000$ ind $\mathrm{m}^{-2}$ ) were located outside the bay in the north of Cancale and a significant northward export of larval cohort was reported along the Cotentin coast on a distance of 60 $\mathrm{km}$ from Granville (> 2,000 ind $\mathrm{m}^{-2}$ ) (Fig. 3C). Larval densities reached only 2,900 and 2,000 ind $\mathrm{m}^{-2}$ above the adult reefs of Champeaux and Sainte-Anne respectively. After 10 weeks, the settlement rate within the bay is equal to $3.19 \times 10^{-4} \%$.

On the contrary, following a larval release from Champeaux, a larger proportion of larvae remained confined in the innermost part of the bay (Fig. 3E). After 6 weeks of dispersal, highest larval 
concentrations were observed in the gyre off Cancale $\left(>3,000\right.$ ind $\left.\mathrm{m}^{-2}\right)$ and within the bay $(>2,000$ ind $\mathrm{m}^{-2}$ ) (Fig. 3F). Larval concentrations above the adult reefs of Champeaux and Sainte-Anne were of 800 and 1,000 ind $\mathrm{m}^{-2}$, respectively. The northward extension of the larval patch along the Normandy coast did not exceed $30 \mathrm{~km}$ from Granville. The settlement rate after 10 weeks reached $2.39 \times 10^{-3} \%$.

These patterns will be used afterwards as reference conditions to assess the influence of tides and winds on larval dispersal.

\subsubsection{Influence of larval release duration}

The dispersal patterns were not modified if larval release occurred uniformly and continuously during 1 tidal cycle or semi-continuously and symmetrically during 3 or 5 tidal cycles (data not shown). Likewise, the total settlement rates from Sainte-Anne and Champeaux did not significantly vary with the larval release duration (Fig. 4). The settlement rate from Sainte-Anne ranged from $8.87 \times 10^{-4}$ to $9.03 \times 10^{-4}$ while the settlement rate from Champeaux varied from $2.39 \times 10^{-3}$ to $2.63 \times 10^{-3}$ with a lightly lower settlement rate when the larval release was instantaneous.

\subsubsection{Influence of the lunar tidal cycle at spawning time}

Without wind forcing, the stages of the spring-neap tidal cycle at larval release had different consequences on the settlement success of larvae according to the emission reef (Fig. 5). For larvae released from Sainte-Anne, the settlement success did not depend significantly on the tidal range at spawning date: the retention rate varied slightly between $2.17 \times 10^{-4}$ and $3.47 \times 10^{-4} \%$ (Fig. 5A) while the colonization rate fluctuated between $3.79 \times 10^{-4}$ and $5.67 \times 10^{-4} \%$ (Fig. 5B). On the contrary, the settlement rates of larvae released from Champeaux significantly decreased with the tidal range (Spearman rank correlation coefficient $r_{s}=-0.834$ with $p$-value $<0.001$ for the retention rate and $r_{s}=-0.883$ with $p$-value 
$<0.001$ for the colonization rate). At this site, the retention rate decreased from $2.11 \times 10^{-3}$ to $7.13 \times 10^{-4} \%$ when the tidal range increased from 3.3 to $12.2 \mathrm{~m}$ (Fig. 5A). In average, it was about twice smaller for a release in spring tide $\left(8.68 \times 10^{-4} \% \pm 0.82 \times 10^{-4} \%, \mathrm{n}=7\right)$ than in neap tide $\left(15.9 \times 10^{-4} \pm 3.5 \times 10^{-4}, \mathrm{n}=7\right)$. Likewise, the colonization rate from Champeaux to Sainte-Anne decreased from $19.3 \times 10^{-4}$ to $5.34 \times 10^{-4} \%$ for a rise in the tidal range from $3.3 \mathrm{~m}$ to $12.2 \mathrm{~m}$ (Fig. 5B). The mean percentage of larvae released at Champeaux and successfully settling at Sainte-Anne showed a twofold decrease between a spring tide spawning $\left(6.78 \times 10^{-4} \% \pm 0.95 \times 10^{-4} \%, \mathrm{n}=7\right)$ and a neap tide one $\left(14.5 \times 10^{-4} \% \pm 2.5 \times 10^{-4} \%, \mathrm{n}=7\right)$. Even if retention and colonization rates were always higher for larvae released at Champeaux rather than at Sainte-Anne whatever the tidal range, maximal differences between both reefs were observed for a spawning at neap tide. In these conditions, the retention rate in Champeaux may be seven times higher than the retention rate in Sainte-Anne while the colonization rate from Champeaux may be five times higher than the colonization rate from Sainte-Anne. For a release in average tide from Champeaux, the variability of the settlement rates was due to tidal conditions the days following the larval release (neap or spring tide).

The ratio of allochthonous settlers vs. autochthonous settlers varied according to the reefs and the tidal range (Fig. 5C). Since the settlement of the larvae released from the Sainte-Anne reef was mostly independent of the tidal range during the spawning, the variation of this ratio was directly due to the variation of the number of settlers from Champeaux. At Sainte-Anne, the ratio decreased from 1.31 to 0.34 when the tidal range increased (Fig. 5C). While the settlement at this reef depended rather on allochthonous settlers for a release in neap tide, settlers were mainly autochthonous for a release in average or spring tide. At Champeaux, the ratio increased from 0.99 to 3.49 when the tidal range increased indicating that the proportion of allochthonous settlers became increasingly important (Fig. 
5C). For a release at spring tide, allochthonous settlers at Champeaux could be 3 times more abundant than autochthonous settlers.

The effect of the lunar tidal cycle at spawning time on the settlement success of larvae released at Champeaux was related to the role of this environmental parameter on the dispersal pattems (Fig. 6). Only a few days after spawning, differences in larval dispersal were already reported according to the tidal range so that the transport to the south was amplified for a release in spring tide (Fig. 6D) in comparison with a release in neap tide (Fig. 6A). After 3 weeks of dispersal, most larvae were located in

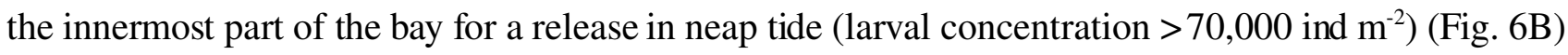
whereas larvae were mainly trapped in the gyre off Cancale for a release in spring tide (larval concentration $>30,000$ ind $\mathrm{m}^{-2}$ ) (Fig. 6E). At larval competency, after 6 weeks of dispersal, even if the extent of the larval cohort was similar whatever the tidal range at spawning time, large spatial variations in larval distribution were still apparent: larval concentrations within the bay were higher for a release in neap tide $\left(>\right.$ 3,000 ind $\mathrm{m}^{-2}$ ) (Fig. 6C) than for a release in spring tide $\left(>1,000\right.$ ind $\left.^{-2}\right)$ (Fig. 6F).

\subsection{Influence of wind conditions on larval dispersal and settlement}

\subsubsection{Seasonal variability of larval settlement under realistic meteorological conditions}

Results for bimonthly larval releases from March to October 2002 under real wind conditions (releases at high tide during average tide conditions) indicated that a realistic wind forcing influenced larval settlement within the bay and could induce a seasonal variability in the success of the larval cohorts (Fig. 7). However, the effect of this forcing showed some variations according to the release reef.

For a release at Champeaux, the wind forcing in 2002 tended to have no effect or to slightly decrease the retention rate (average retention rate of $1.09 \times 10^{-3} \pm 0.47 \times 10^{-3} \%$ with wind forcing $v s .1 .23 \times 10^{-3} \pm$ $0.15 \times 10^{-3} \%$ without wind forcing) except for 3 spawning events (Fig. 7A). Thus, the retention rate in 
Champeaux was increased about 1.5 folds for the larvae released on 10 May, 23 May and 4 October. Likewise, the colonization rate from Champeaux to Sainte-Anne was generally smaller than those obtained without wind forcing (average colonization rate of $0.81 \times 10^{-3} \pm 0.43 \times 10^{-3} \%$ with wind forcing $v s$. $1.18 \times 10^{-3} \pm 0.16 \times 10^{-3} \%$ without wind forcing) (Fig. 7B). Only larvae released on 10 May exhibited a twofold increase in the colonization rate of Sainte-Anne reef in the presence of wind forcing.

By contrast, the retention and colonization rates of larvae released from Sainte-Anne could be strongly modified by the meteorological conditions in 2002 . The wind forcing strongly enhanced the retention rates for 6 spawning events out of 16, from the end of April to the end of June and in midOctober (Fig. 7C). In comparison with no wind forcing, the retention was multiplied by about 3 for a larval release on 24 April and 22 June, by 4.5 for a release on 19 October, by 5.4 for a release on 9 June and by about 6.5 for a release on 10 and 23 May. For the other 10 spawning events, the retention rates obtained under real wind forcing are close to those obtained without wind forcing. Because of wind forcing, the colonization rate from Sainte-Anne to Champeaux was also strongly increased at the same dates, from a factor 1.6 for a larval release on 24 April to a factor 9.8 for a larval release on 23 May (Fig 7D).

The maximum increase in the retention and colonization rates of larvae released at Sainte-Anne was achieved with a nearly constant westerly or south-westerly wind as shown for larval releases on 10 May, 23 May and 19 October 2002 (Fig. 8). Other wind conditions generated dispersal patterns comparable to those obtained with tidal forcing only. If the maximal extent of the larval cohort after 6 weeks of dispersal was slightly modified by wind forcing (compare with Figs. $3 \&$ 6), the location of the highest larval concentrations was highly dependent on meteorological conditions.

For a release on 10 May 2002, larvae were subjected to a SW wind for the first 3 weeks, and then 
alternatively to $\mathrm{NW}$ and $\mathrm{W}$ winds (mean velocity of $5.3 \mathrm{~m} \mathrm{~s}^{-1}$ ) (Fig. 8C). After 3 and 6 weeks of dispersal, larvae were mainly located within the bay and in the gyre off Cancale (Fig. 8A-B). At both periods, the highest larval concentrations ( $>120,000$ and 15,000 ind $\mathrm{m}^{-2}$ respectively) were confined in the southeastern part of the bay. For a release on 19 October 2002, the wind was mainly from W- SW and then S (average velocity of $\left.6.86 \mathrm{~m} \mathrm{~s}^{-1}\right)$ except for a 2-week period characterized by an E wind $\left(5.90 \mathrm{~m} \mathrm{~s}^{-1}\right)$ (Fig. $8 \mathrm{~L})$. After 3 weeks of dispersal, larval distribution was close to the one obtained for a release on 10 May with maximal concentrations ( $>150,000 \mathrm{ind}^{-2}$ ) reported in the south-eastern part of the bay (Fig. 8J). After 6 weeks, the $\mathrm{S}$ wind forcing resulted in a larval transport to the north along the Normandy coasts with maximal larval concentrations (> 15,000 ind $\mathrm{m}^{-2}$ ) between Champeaux and Granville (Fig. 8K). For both release dates, the different wind conditions induced very similar enhance of colonization rate while the increase in the retention rate was stronger for a release on 10 May.

For a release on 23 May 2002, larvae were subjected to a fairly constant $\mathrm{W}$ wind with some short NW wind events (mean velocity of $4.8 \mathrm{~m} \mathrm{~s}^{-1}$ ) (Fig. 8F). In response to this forcing, the quantity of larvae trapped in the gyre off Cancale remained low. After 3 and 6 weeks of dispersal, maximal larval concentrations ( $>200,000$ and 24,000 ind $\mathrm{m}^{-2}$ ) were confined in the eastern part of the bay (Fig. 8D-E), explaining the large increase of the colonization rate from Sainte-Anne to Champeaux.

During the dispersal of the larvae released on 21 August 2002, wind blew from NE during the first 7 weeks (mean velocity of $4.3 \mathrm{~m} \mathrm{~s}^{-1}$ ) and then from SW during the last 3 weeks (mean velocity of $6.8 \mathrm{~m} \mathrm{~s}^{-1}$ ) (Fig. 8I). These wind conditions leaded to larval dispersal patterns similar to those observed without wind forcing so that larvae were mainly located outside the bay, either trapped in the gyre off Cancale or transported northwards along the Cotentin coast (Fig. 3B-C, Fig. 8G-H). 


\subsubsection{Year-to-year variability of larval settlement under realistic meteorological conditions}

Variations in meteorological conditions induced high intra- and inter-annual variability of the larval settlement (i.e. origin and number of settlers) as shown from the simulations of monthly spawning events under real wind forcing from April to October between 2000 and 2004 (Fig. 9). The number of settlers varied by a factor 3 to 4 within a year while the most favourable period for settlement varied among years. The highest settlements were obtained in October in 2000, in July, August and October in 2001, in May and June in 2002, in May in 2003 or in April in 2004. As already mentioned, variations in settlement were mainly related to the meteorological conditions encountered by larvae through their life span. For instance, for the spawning events simulated in May, only the wind conditions observed in 2002 and 2003 were favourable to high settlements. For both years, the wind blew from SW for the first 3 weeks and then mainly from $\mathrm{W}$ with an average velocity of 5.3 and $4.4 \mathrm{~m} \mathrm{~s}^{-1}$ respectively. By contrast, larvae released in May 2000, 2001, and 2004 were subject to changing wind conditions (NE then W and SW in 2000; NE, NW and W in 2001; W, N and W in 2004) that induced lower settlements.

At the scale of the bay, the highest settlements were mainly due to the high retention and colonization rates of larvae released from the Sainte-Anne reef. Indeed, for those spawning events, the abundance of both autochthonous settlers in Sainte-Anne and allochthonous settlers in Champeaux were strongly increased, except for the spawning of October 2000 for which only the allochthonous settlers in Champeaux was enhanced (Fig. 9). Settlers from Sainte-Anne represented between 42.1 and $95.3 \%$ of the total number of settlers in the bay whereas larvae released at Sainte-Anne represented $84 \%$ of the reproductive output during one spawning event. Settlement at the Sainte-Anne reef was mainly due to local larval supply (mean allochthonous settlement ratio of $0.59 \pm 0.47$ ) while settlement at the Champeaux reef resulted from distant larval supply (mean allochthonous settlement ratio of $3.83 \pm 4.03$ ). 


\subsection{Settlement kinetics and metamorphosis delay}

To evaluate the influence of the capacity of competent larvae to delay metamorphosis, the settlement kinetics was analyzed for all the simulations. As an example, Fig. 10 provides the cumulative number of settlers following a larval release at Sainte-Anne, from the beginning to the end of the settlement period; 4 distinct spawning events for which larval dispersal has been already described have been selected (see Fig. 8). Although the final settlers' abundance was highly variable depending on the spawning date, the settlement kinetics for larvae retained locally or colonizing the Champeaux reef was similar for most spawning events. Thus, for a larval release on 10 May, 21 August and 19 October 2002, the cumulated number of settlers increased sharply during the first week of the settlement and reached an asymptote after 10-15 days. Conversely, for some spawning events” the settlement kinetics was more complex. For a larval release in Sainte-Anne on 23 May 2002, the temporal evolution of the number of local settlers increased regularly over the first 15 days while the evolution of the number of colonizers occurred in 2 steps: one between 0 and 5 days and one between 8 and 15 days (Fig. 10B). The hydroclimatic conditions encountered by larvae after this spawning (i.e. mainly western wind) ensured the transport of competent larvae to the eastern part of the bay that favoured a strong and regular colonization rate of the Champeaux reef over 2 weeks and a low initial settlement rate of the Sainte-Anne reef over 5 days (see Fig. 7B). However, a short event of northern wind between 50 and 55 days after the spawning promoted a slight westwards transport of larvae above the Sainte-Anne reef that induced a second local settlement phase 9 days after the settlement beginning. Such a result suggests that the delay of the metamorphosis could significantly improve the settlement success within the bay in response to short-term variations in larval transport. 
The total number of settlers varied according to the minimal planktonic larval duration, i.e. the age at competence (Fig. 11). For an instantaneous larval release and a without wind forcing dispersal, the total number of settlers decreased exponentially from $1.43 \times 10^{10}$ to $7.04 \times 10^{8}$ when the age at competence increased from 4 to 8 weeks. This exponential decrease in settlers' number obtained for a longer minimal PLD was mainly related to larval losses through natural mortality and in a lesser extent to an increase in larval export. However, such quantitative variations in the PLD did not alter larval dispersal patterns or the relative influence of the two reefs to the replenishment of adult populations.

\section{Discussion}

Field observations performed in 2002 have shown that large-scale spatial distribution of Sabellaria alveolata larvae was patchy and was mainly controlled by residual currents (Dubois etal., 2007). Highest densities (up to 28,000 larvae $\mathrm{m}^{-2}$ ) were generally located in nearshore waters close to the adult reefs or were trapped within the gyre off Cancale. A northward extension of the larval patch was also reported along the western coast of Normandy with larval densities reaching about 100 larvae $\mathrm{m}^{-2}$. Although these observations highlighted a potential larval retention within the bay, the lack of long-term observations hampered evaluating the consequences of larval supply variability on the large year-to-year variations in recruitment reported in the Bay of Mont-Saint-Michel (Gruet, 1986). Furthermore, the role of the connectivity between the two Sabellaria reefs on settlement dynamics within the bay remained unknown. As an alternative, we used in the present study a 3D hydrodynamic model with a numerical code already evaluated on the NW European continental shelf (Lazure and Dumas, 2008) or in a coastal shallow embayment (Plus et al., 2009). It provided simulated results which were qualitatively in good agreement with spatial and temporal larval field surveys (Dubois et al., 2007). Even if absolute values of settlement 
might be uncertain due to biological simplifications (e.g. no seasonal variations in larval release, constant larval mortality rate, passive behaviour), the variations of these values in response to spatial and temporal variations of physical forcing remained meaningful and could be studied in a sensitivity analysis.

\subsection{Relative importance of hydrodynamic processes}

Simulated larval dispersal patterns and settlement success were highly variable between the two reefs although they were located only $15 \mathrm{~km}$ apart. Settlement success was generally lower for the larvae released from the Sainte-Anne reef than for the larvae from the Champeaux reef, especially without wind forcing. On the other hand, settlement success of larvae from Champeaux varied mainly in response to variations in tidal conditions at spawning date while settlement success of larvae from Sainte-Anne was more dependent on meteorological conditions during dispersal. These discrepancies between the two parental reefs due to their spatial location indicate that small-scale and nearshore physical processes play an important role in larval transport and could vary at the scale of a few kilometers (Largier, 2003). As previously pointed out by several studies investigating the importance of scale griding in larval dispersal modelling (Guizien et al., 2006, Baums et al., 2006), our work underlines the necessity of developing models whose spatial resolution is adapted to the scale of the predominant hydrodynamical features of the study area.

Without wind forcing, larvae released from Sainte-Anne were quickly transported to the West of the bay and then exported northwards through the gyre off Cancale. Afterwards, they either remained trapped within the gyre or were transported along the western coasts of Normandy. Since most larvae were already locatedoutside the Bay of Mont-Saint-Michel within a few weeks after the spawning event, settlement success was low and was not affected by the tidal conditions during larval release. Conversely, 
larvae released from Champeaux were slowly transported to the West. A significant part of the larval patch was maintained in the inner part of the bay during the whole larval life span while some larvae were flushed outside the bay, within the gyre off Cancale or along the Normandy coasts. Therefore, such retention within the bay promoted the settlement success of larvae released from Champeaux but varied with tidal conditions at spawning. Settlement rates decreased when the tidal range, and consequently tidal currents, increased. Hence, for a larval release at Champeaux during a neap tide, slower currents advected larvae that remained close to the shore on shorter distances alongshore in comparison with a larval release during a spring tide: larval retention in the innermost part of the bay was increased while the larval "flushing" outside the bay was decreased.

The transport of the larval cohort at the very beginning of the dispersal appeared to be primordial for the rest of the larval dispersal and the settlement success, suggesting that larval fate could be determined very early in the larval life span (Verdier-Bonnet et al., 1997).

Although no information occurs on spawning trigger mechanisms for Sabellaria alveolata, mechanical action of the flood currents on mature females has been reported to induce larval release for some intertidal polychaetes (Bentley and Pacey, 1992) and wave activity has been shown as tightly linked with spawning events in the sabellariid reef-building polychaete Phragmatopoma lapidosa (McCarthy et al., 2003). Chemical cues related to phytoplankton blooms and/or sperm from conspecifics have also been reported to promote massive spawning in widely separated invertebrate phyla (Starr et al., 1990). On the other hand, the influence of the lunar or the tidal cycle upon spawning has been demonstrated in many marine polychaetes which spawn coincidentally either with spring tides or neap tides (Bentley and Pacey, 1992). In the present model, the mathematical formulation of larval release (i.e. instantaneous, continuous and uniform over a tidal cycle, semi-continuous and symmetric over 3 or 5 tidal cycles) had no significant 
effect on the settlement rates, suggesting that the simplistic formulation of this biological mechanism retained for most simulations (i.e. instantaneous release) did not alter our conclusions on the relative role of hydrodynamic processes. Conversely, if Sabellaria alveolata spawning occurs in relation to lunar cycle, this mechanism might significantly influence settlement success of larvae released from Champeaux, by preventing their export out of the bay for a release in neap tide.

Although tidal residual currents are the main cause of the long-term water mass transport in the English Channel, wind-induced currents can play a significant role at shorter time scales and have been described to prevail in the variability of larval dispersal (Lagadeuc, 1992; Ellien et al., 2004). Wind conditions can greatly modify the larval dispersal patterns and ultimately increase or decrease the settlement success by altering the local circulation. Such effect was particularly observed for larvae released from Sainte-Anne with a settlement success varying by one order of magnitude according to realistic meteorological forcing. As already reported for the tide effects on larval dispersal, settlement success was high when wind-induced hydrodynamic conditions constrained the larvae within the bay since larval release. Thus, the occurrence of SW and NW winds decreased the spatial extension of the gyre off Cancale, slowed down residual currents in the inner part of the bay, and increased the residence time of larvae within the bay. Over the reproductive period of Sabellaria alveolata, the variations in the meteorological conditions should induce a very high seasonal and inter-annual variability of larval dispersal patterns (Ellien et al., 2004; Pedersen et al., 2006) and settlement success (Botsford, 2001). The co-occurrence of particular wind conditions and high recruitment events have been commonly reported for several species with a pelagic dispersive stage in different coastal environments like the blue crab Callinectes sapidus in the Middle Atlantic Bight (Jones andEpifanio, 1995) or several species of crabs, sea urchins and sea stars in the Northern California (Wing et al., 1995). 
The consequences of this variability on population sustainability would vary according to the temporal scales of observation. Within a year, high settlements would occur only if larvae are released in a temporal window favourable to larval retention. If such a window seemed to be present each year, the period at which it has been simulated was highly variable from one year to another (e.g. October in 2000, May in 2003, April in 2004), suggesting that the date of massive settlements could vary among years. Furthermore, while the Sabellaria alveolata reproductive period has been estimated to extend from March to October, larval release is not continuous and two main periods of spawning have been identified in May-June and in September (Dubois, 2003; Dubois et al., 2007). From our simulations under realistic meteorological conditions for the years 2000 to 2004, a larval release in May-June or September could lead to very high settlements only for some particular years like 2002 or 2003 . The presence or the absence of an optimal environmental window during the two main spawning periods may explain the large year-to-year variations in recruitment success although other causes could be proposed including post-settlement mortality (Wilson, 1971). Moreover a spatio-temporal field survey carried out in 2001 has revealed a very low concentration of S. alveolata larvae compared to the same 2002 field survey (Dubois, 2003; Dubois et al., 2007), hence supporting the idea of large year-to-year variability in optimal environmental windows. On the other hand, at temporal scales relevant to the life history of the organism, an extended spawning period from spring to autumn could increase the likelihood that larval cohorts benefit some years of favourable hydroclimatic conditions. For an iteroparous species, Byers and Pringle (2006) showed that multiple spawning events over multiple years increase the variability of hydrodynamics encountered by the larvae produced by an individual and enhance larval retention. Although numerous larvae may be transported away from local populations, an extended reproductive period can be described as an efficient strategy to maximize retention and long-term sustainability of 
adult populations.

The complex role of eddy structures on larval dispersal and retention has been recently pointed out (Largier, 2003; Baums et al., 2006). Thus, eddies are commonly reported to cause trapping of particles and act as a crossing barrier to larval dispersal, enhancing local retention and settlement. On the other hand, coastal eddies can concentrate larvae from different source populations and promote the connectivity among populations. In the English Channel, two types of eddies were distinguished in a recent work based on a steady state modelling analysis: gyres around islands that form strong dissemination areas, and headland eddies that constitute tracer accumulation area (Ménesguen and Gohin, 2006). Our results are coherent with this description which classifies the gyre off Cancale as a retention structure and confirm field observations on meroplankton distribution suggesting that this gyre may act as a physical trap for Sabellaria alveolata larvae (Dubois et al., 2007). Nevertheless, as eddies occur on many spatial and temporal scales, their efficiency to promote larval retention and enhance local settlement depends on their life time relative to larval life span and on their size relative to the spatial extent of the benthic population (Largier, 2003). In our case, simulated depth-averaged residual currents highlighted the long-term persistence of the gyre off Cancale for different wind directions and a wind velocity $<11 \mathrm{~m} \mathrm{~s}^{-1}$. Such a velocity is rarely exceeded during Sabellaria alveolata reproductive period from April to October between 2000 and 2004 (i.e. less than $0.75 \%$ of daily wind measurements) and one can assume that the gyre off Cancale acts as a retention area during the whole Sabellaria larval life span. By contrast, the extent of the gyre largely exceeded the restricted habitat occupied by Sabellaria reefs. Thus, depending on the variability of meteorological conditions, the geographical location and the spatial extent of the gyre off Cancale were highly variable with either positive or negative effects on the settlement of Sabellaria alveolata larvae. Settlement success was promoted only if competent Sabellaria 
larvae were transported above the reefs by the currents. The lowest settlement rates were then simulated when most larvae were advected outside the bay and were then trapped in the gyre in the North of Cancale. Conversely, the highest settlement rates were reported when larvae were early constrained in the inner part of the bay and were maintained there close to adult reefs. This situation occurred when western winds constrained the location and the extent of the gyre within the bay.

\subsection{Relative role of biological parameters}

Larval dispersal results from interactions between hydrodynamic features and biological factors including spawning location and date, as already discussed above, but also planktonic larval duration, capacity to delay metamorphosis, larval mortality, and larval behaviour. Compared to an individual-based model, individual variability has not been taken into account in our Eulerian approach of larval dispersal. However, an individual-based model of larval dispersal including individual variability of vertical behaviour and some population dynamics parameters cannot be parametrize currently as deeper knowledge of the Sabellaria alveolata larval biology in response to environmental variability is still lacking. In this context, our results yet allow to discuss the limitation of setting simple biological traits in dispersal models.

Larval mortality is a parameter of the larval biology that remains poorly known for most marine benthic invertebrates because of the difficulties to obtain accurate estimates from field studies and of its large variability among species and environments (Rumrill, 1990). Usually, in larval dispersal model, the mortality term is either neglected or arbitrary fixed while a misrepresentation of the larval mortality can alter the simulated larval distribution (Dekshenieks et al., 1997) or biased the estimations of local larval supply and connectivity between distant populations (Cowen et al., 2000; Ellien et al., 2004). As an 
example, retention is more likely than expected when model incorporates mortality (Cowen et al., 2000). Here, to be as realistic as possible, we used a mortality rate obtained from bi-monthly field observations of Sabellaria larval densities at four stations in the Bay of Mont-Saint-Michel $\left(\mu=0.09 \mathrm{~d}^{-1}\right)$. This value was in good agreement with the range of mortality rate reported for 23 species of marine invertebrates by Rumrill $(1990)\left(\right.$ mean $=0.229 \mathrm{~d}^{-1} ; \mathrm{SD}=0.228 ;$ range $=0.016$ to $\left.0.820 \mathrm{~d}^{-1}\right)$. However, we assumed that there was no spatial and temporal variation in mortality rate. Larval mortality can result from unfavourable environmental parameters such as temperature and food availability, predation, and intrinsic individual variability (Rumrill, 1990). The unfavourable environmental conditions rarely induce a direct mortality, but rather an indirect one, by prolonging the planktonic larval duration and consequently enhancing the exposition to predation and larval transport (O'Connor et al., 2007). In the Bay of MontSaint-Michel, the lack of strong hydrological gradients may justify the assumption of no spatial variation in the mortality rate due to environmental conditions (Dubois et al., 2007). By contrast, the seasonal variations of temperature and chlorophyll $a$ concentrations over the extended reproductive period of Sabellaria from April to October may induce a seasonal variation in the planktonic larval duration and the mortality rate. This variation would not affect the relative differences between reefs in the numbers and origins of larvae for each spawning event. But it should strongly influence the prediction of the absolute values of settlers' density and strengthen the seasonal variation in the settlement rate already described in relation to seasonal changes in meteorological variations. Indeed, Sabellaria alveolata has a long planktonic larval duration which can generate high larval losses because of larval mortality and larval export away from the adult reefs which form a very restrictive habitat. The sensitivity analysis performed on the planktonic larval duration indicated that a longer PLD induced lower settlers' density because of higher larval losses through mortality. On the other hand, numerous shellfish farming 
structures are located in the south-western part of the bay which could induce spatially heterogeneous mortality due to predation by cultivated oysters and mussels (Lehane and Davenport, 2006; Troost et al., 2008). This stronger mortality above oyster and mussel beds may preferentially affect young larvae released from the Sainte-Anne reef or competent larvae able to settle on this reef, suggesting that the role attributed to the Sainte-Anne reef on the dynamics of Sabellaria recruitment at the scale of the bay may be overvalued.

In the present model, precompetent larvae were considered as completely passive, while competent larvae were able to actively select the settlement habitat. This assumption of passive dispersal in our case can be justified by several reasons in a first approximation. First, because of very low freshwater inputs and rapid vertical mixing of the entire water column due to intense tidal currents, the transport in the Bay of Mont-Saint-Michel is mainly governed by barotropic processes with limited vertical current shear stress. Second, from a $24 \mathrm{~h}$ time series on Sabellaria alveolata vertical larval distribution at one station in the bay, Dubois et al. (2007) indicated the absence of diel or ontogenic migration but mentioned a variation in the centre of mass of the larval vertical distribution according to the tidal cycle: higher larval concentrations were close to the surface during flood and close to the middle of the water column during ebb. If such larval migration known as selective tidal stream transport is commonly reported to enhance larval retention by favouring landward transport, its effect in the bay would be reduced due to the low variations in current velocities between the top and the middle of the water column. Third, in a recent review on larval transport, Bradbury and Snelgrove (2001) argued that passive mechanisms are probably predominant at broad scales for most marine invertebrates because of their poor swimming abilities but that active habitat selection and the capacity to delay metamorphosis can be prevalent at local scales. In fact, invertebrate larvae are complex organisms able to control their distribution over a wide range of 
spatial and temporal scales and to develop specific behaviour to feed, avoid predation or move within the pelagic environment (Levin, 2006; Woodson and McManus, 2007). Field studies have already reported vertical migrations for marine invertebrate larvae, including polychaetes, with a significant effect on larval transport, promoting either larval retention or larval export (Levin, 2006; Dubois et al., 2007). Recent modelling approach have highlighted that the explicit consideration of larval behaviour is essential to simulate larval dispersal, even with restricted larval swimming abilities (e.g. North et al. 2008; Cowen and Sponaugle, 2009). However, if behaviour can be easily implemented in individualbased models, numerous field and laboratory experiments are necessary to properly describe the specific behavioural responses of organisms to environmental cues and avoid the use of simple and likely unrealistic behaviours. By neglecting the tidal variations in the vertical distributions of Sabellaria larvae, one can just expect that our model has tended to underestimate larval retention.

Conversely, the 3D modelling in our study allowed us to take into account an active settling behaviour. It is nevertheless crudely parametrised because of the lack of information on the maximal distance from which competent larvae are able to perceive the chemical cues produced by the adult worms (Wilson, 1968a; Wilson, 1970) or on the optimal range of hydrodynamic conditions for settlement (Pawlick and Butman, 1993). Furthermore, the complex topography of Sabellaria reefs and its influence on flow conditions in the benthic boundary layers could not be properly described in our model with horizontal grid of $800 \mathrm{~m}$ and 10 sigma levels.

In our simulations the larvae became competent after 6 weeks of dispersal but were able to delay they metamorphosis 4 more weeks. The settlement kinetics indicated that the majority of the larvae actually settled during only the first 10 days following the beginning of the settlement period and that the number of larvae that settled later decreased shaply. Although the number of settling larvae was very 
low during the last days of the dispersal, the ability to delay metamorphosis may give to the competent larvae a "second chance" to settle, as observed for the autochthonous settlers in Sainte-Anne for the release of the 23 May 2002. As commonly reported, such results tend to confirm that delaying metamorphosis could be a benefit for a larva by enhancing its likelihood of locating a suitable site for metamorphosis, at least for a short period. This benefit should be important all the more as the planktonic larval duration will be short and larval densities near natal sources will be still high. Conversely, for some species this property could affect the post-metamorphic success of individuals in terms of survival or growth rate (Pechenik et al., 1993).

\subsection{Sustainability of the reefs}

The largest biogenic reefs of the European coasts are the Sabellaria alveolata reefs of the Bay of Mont-Saint-Michel. A previous study on the in situ distribution of the Sabellaria alveolata larvae in the Bay of Mont-Saint-Michel (Dubois et al., 2007) highlighted the role of the tidal residual currents, especially of the gyre off Cancale, on the larval retention in the bay, but the connectivity between the two reefs of the bay remained unknown. The present work brings answers about the intensity and the variability of the potential larval exchanges between the two Sabellaria alveolata reefs of the Bay of Mont-Saint-Michel. Our results indicated that despite very low settlement rates (i.e < $0.004 \%$ ), the hydrodynamic specificities of the bay could allow larval retention at the bay scale and favour the larval exchanges between the two reefs. At the bay scale, and as long as the larval supply remains high, existing reefs (and potentially newly formed reefs) could benefit of favourable hydroclimatic conditions all along the long reproductive period, especially if the spawning occurs in neap tide conditions, or under retention-favourable meteorological conditions as SW and NW winds. Previous studies have highlighted 
the importance of local scale retention and self-recnuitment in the population dynamics of bentho-pelagic organisms (Cowen and Sponaugle, 2009). Considering the spatial scale of the larval dispersal of Sabellaria alveolata in the Gulf of Saint-Malo, larvae from the reefs of the Bay of Mont-Saint-Michel could supply some small veneers (thin honeycomb reefs adhering to rocks) along the Normandy coasts, but larval supplies from distant populations are unlikely. Contrary to a source-sink hypothesis of one-way exchanges from the biggest reef of Sainte-Anne to the smaller reef of Champeaux, the present work indicated that the two reefs freely exchange individuals through the larval dispersive stage, as supported by a microsatellite genetic analysis (Farcy, 2003).

Although the simulated settlers' density could be quite sensitive to the mortality term (Cowen et al., 2000; Ellien et al., 2004), the highest numbers of settlers calculated from our simulations were in the same order of magnitude as the adult stocks within the bay. If those high larval supplies occur often enough compared to the life span of adult individuals, this might be sufficient to sustain the reefs in the bay. In our simulations the Sainte-Anne reef is responsible for the main larval supply in the bay because of its high reproductive outputs. However the adult stocks in the Sainte-Anne reef dramatically decreased since 2002, because of both the fragmentation and the colonization of the reef by the cultivated oyster Crassostrea gigas (Dubois, Desroy, and Le Mao, pers. obs.). Moreover the development of shellfish farming, which is responsible for high abundances of cultivated oysters and mussels in the bay, could also induce high larval mortality and contribute to a strong decrease of the larval supply, especially in SainteAnne (Dubois et al., 2007). In this context, the huge decrease in the reproductive outputs of the SainteAnne reef could adversely affect the sustainability of the two reefs of the Bay of Mont-Saint-Michel. If the Sainte-Anne reef disappears our results suggest that, even if larval retention occurs, the larval supply from Champeaux might not be sufficient enough to sustain itself and recolonize the Sainte-Anne reef. 
Since bidirectional larval exchanges exist between the two reefs, conservation policies should focus on the protection of both reefs, with special interest for the protection of the declining Sainte-Anne reef which is responsible under favourable conditions for the highest larval supply.

This modelling study underlined the crucial role played by hydroclimatic conditions in larval dispersal and connectivity of the Sabellaria alveolata reefs in the Bay of Mont-Saint-Michel, but also pointed out the lack of precise knowledge of the Sabellaria larval biology. Significant efforts should be made in future experimental and in situ works in order to precisely evaluate the parameters of the larval biology, in particular the larval swimming behaviour, the larval mortality rate, and the planktonic larval duration, as a function of individual and environmental parameters such as ontogeny, temperature, food availability, or predation pressure. In this context, a more precise knowledge of the larval biology will be a central issue for the development of future dispersal models and for a more accurate evaluation of the role of the larval phase on the reefs' sustainability.

\section{Acknowledgements}

The present study was financed by the French National Programme on Coastal Environment (PNEC) Site Atelier 'Baie du Mont-Saint-Michel'. S.-D. Ayata is supported by a $\mathrm{PhD}$ grant from the French Ministry of National Education and Research. The authors are grateful to Dr J.E. Eckman and two anonymous reviewers for their helpful comments on the first version of the manuscript. 


\section{Appendix 1 - Hydrodynamic model}

The Model for Applications at Regional Scale (MARS), is a primitive equation, finite-difference model (Lazure \& Dumas, 2008). It is solved in a sigma coordinate framework such as:

$$
\sigma=\frac{\zeta+H}{\zeta+H}
$$

with $\sigma$, the vertical coordinate, $H(x, y)$, the absolute value of bottom position, and $\zeta(x, y)$, the sea surface elevation, with $z$ and $\sigma$ increasing upward. The water column height is then $D(x, y)=H(x, y)+\zeta \quad(x, y)$. To simplify the writing of any advection term of any variable $A$, the following notation $L(A)$ is used:

$L(A)=u \frac{\partial A}{\partial x}+v \frac{\partial A}{\partial y}+w * \frac{\partial A}{\partial \sigma}$

with $u$, the zonal velocity, $v$, the meridional velocity, and $w^{*}$, the vertical velocity in the sigma coordinate framework $(x, y, \sigma)$.

$w * i \frac{1}{D}\left(w-\sigma \frac{\partial \zeta}{\partial t}-u\left(\sigma \frac{\partial \zeta}{\partial x}+(\sigma-1) \frac{\partial H}{\partial x}\right)-v\left(\sigma \frac{\partial \zeta}{\partial y}+(\sigma-1) \frac{\partial H}{\partial y}\right)\right)$

with $w$, the vertical velocity in the physical framework $(\mathrm{x}, \mathrm{y}, \mathrm{z})$.

The conventional Boussinesq and hydrostatic approximations are used to solve the Navier-Stokes equations in the Cartesian coordinates $(x, y, \sigma)$ :

$\frac{1}{D} \frac{\partial \rho}{\partial \sigma}=-\rho g$ 
$\frac{\partial \zeta}{\partial t}+L(D)=0$

$\frac{\partial u}{\partial t}+L(u)-f v=-g \frac{\partial \zeta}{\partial x} \frac{1}{\rho_{0}} \frac{\partial P a}{\partial x} \frac{1}{D} \frac{\partial\left(\frac{n z}{D} \frac{\partial u}{\partial \sigma}\right)}{\partial \sigma}$

$\frac{\eta v}{\eta t}+L(v)+f u=-g \frac{\eta z}{\eta y} \frac{1}{\rho_{0}} \frac{\eta P a}{\eta y} \frac{1}{D} \frac{\eta\left(\frac{n z}{D} \frac{\eta v}{\eta s}\right)}{\eta s}$

with $D(x, y)$, the water column height, the sea surface elevation, $\rho$, the water density as a function of

5 salinity, temperature and pressure, $g$, the gravity, $f$, the Coriolis parameter, $u$, the zonal velocity, $v$, the meridional velocity in the sigma framework $(x, y, \sigma), \rho_{0}$, the reference density of seawater, $\mathrm{P}_{\mathrm{a}}$, the atmospheric pressure at sea level, $\pi_{\mathrm{x}}$ and $\pi_{\mathrm{y}}$, the zonal and meridional components of the baroclinic pressure gradient, $n z$, the vertical eddy viscosity, $\mathrm{F}_{\mathrm{x}}$ and $\mathrm{F}_{\mathrm{y}}$, the horizontal friction terms. The detailed formulations of the Coriolis parameter $f$, the friction terms $\mathrm{F}_{\mathrm{x}}$ and $\mathrm{F}_{\mathrm{y}}$, the eddy coefficient $n z$, and the

10 horizontal components of the baroclinic pressure gradient $\pi_{\mathrm{x}}$ and $\pi_{\mathrm{y}}$ are given in Lazure \& Dumas (2008).

Eddy coefficients are calculated from a 1-equation closure model following a classical $k$ - $l$ formulation well suited for coastal domain (Luyten et al., 1996).

The mode splitting approach leads to build a specific barotropic model by integrating the Eqs 5-7 over the vertical from bottom $(\sigma=0)$ to top $(\sigma=1)$ and considering kinematic boundary conditions:

$15 \frac{\partial \zeta}{\partial t}+\frac{\partial D \bar{u}}{\partial x}+\frac{\partial D \bar{v}}{\partial y}=0$

$$
\frac{\partial \bar{u}}{\partial t}=-g \frac{\partial \zeta}{\partial x}-\frac{1}{\rho_{0}} \frac{\partial P a}{\partial x}+\frac{1}{\rho_{0} D}\left(\tau_{s x}-\tau_{b x}\right)+\int_{\sigma=0}^{\sigma=1}\left[f v-L(u)+\pi_{x}+F_{x}\right] d \sigma
$$


(9)

$$
\frac{\eta \bar{v}}{\eta t}=-g \frac{\eta z}{\eta y}-\frac{1}{\rho_{0}} \frac{\eta P a}{\eta y}+\frac{1}{\rho_{0} D}\left(t_{s y}-t_{b y}\right)+\int_{s=0}^{s=1}\left[-f u-L(v)+p_{y}+F_{y}\right] d s
$$

with $\tau_{\mathrm{sx}}$ and $\tau_{\mathrm{sy}}$, the surface stress components, and $\tau_{\mathrm{bx}}$ and $\tau_{\mathrm{by}}$, the bottom stress components, $\bar{u}$ and $\bar{v}$,

the mean zonal and meridional currents over depth given by $(\bar{u}, \bar{v})=\int_{\sigma=0}^{\sigma=1}(u, v) d \sigma$.

The barotropic model is solved using an Alternate Direction Implicit scheme which is a semiimplicit method. This method is only implicit conceming the direction of the computation. The free

25 surface elevation $\zeta$ is computed every half time step, whereas the mean zonal and meridional currents over depth ( $\bar{u}$ and $\bar{v}$ ) are computed alternatively (i.e. every time step). Computations of $\bar{u}$ and $\zeta$ are performed in a row-wise manner at a given time-step by solving Eqs 6, 8 and 9, whereas computations of $\bar{v}$ and $\zeta$ are performed in a column-wise manner a half time step later by solving Eqs 7, 8 and 10. The use of a spatially centred second order scheme and the staggered Arakawa C grid lead to a tridiagonal

30 linear system being solved using lower-upper factorization.

\section{Appendix 2 - Mathematical formulations of complex larval release}

For an uniform continuous spawning over one tidal cycle, a symmetric semi-continuous spawning over 3

35 tidal cycles and a symmetric semi-continuous spawning over 5 tidal cycles, the larval release term is given by the general equation: 


$$
\begin{aligned}
& \frac{\partial r(x, y, \sigma, t)}{\partial t}=p \frac{N_{0}}{V_{x y \sigma}} \frac{1}{\Delta t} \quad \text { when } \quad t_{b} \leq t<t_{e}=t_{b}+\Delta \mathrm{t} \\
& \{x, y\} \in\{\text { reef coordinates }\} \\
& \sigma=1 \\
& D(x, y)>0.5
\end{aligned}
$$

with $\mathrm{r}$, the larval release function, $\mathrm{N}_{0}$, the total number of larvae released during the spawning event, $\mathrm{V}_{\mathrm{xy} \sigma}$ $=\mathrm{V}_{\mathrm{xy} 1}$ the volume of the lower cell of coordinates $(\mathrm{x}, \mathrm{y}, 1), \mathrm{t}_{\mathrm{b}}$, the beginning time of larval release, $\mathrm{t}_{\mathrm{e}}$, the ending time of larval release, $\Delta \mathrm{t}$ the continuous spawning time duration, and $p$ the percentage of released

40 larvae during $\Delta \mathrm{t}$. The values of $\mathrm{t}_{\mathrm{b}}, \mathrm{t}_{\mathrm{e}}$, and $p$ for each spawning type are given in Table 1 assuming a tidal cycle lasting $12 \mathrm{~h} 20$. In each case, larval release is centred on onehigh tide.

\section{References}

Allain, G., Petitgas, P., Lazure, P., Grellier P., 2007. Biophysical modelling of larval drift, growth and survival for the prediction of anchovy (Engraulis encrasicolus) recruitment in the Bay of Biscay (NE Atlantic). Fisheries Oceanography 16 (6), 489-505.

Bailly du Bois, P., Dumas, F. 2005. Fast hydrodynamic model for medium- and long-term dispersion in seawater in the English Channel and southern North Sea, qualitative and quantitative validation by radionuclide tracers. Ocean Modelling, 9, 169-210.

Baums, I., Paris, C., Chérubin, L.M., 2006. A bio-oceanographic filter to larval dispersal in a reef-building coral. Limnology and Oceanography 51 (5), 1969-1981.

Bentley, M., Pacey, A., 1992. Physiological and environmental control of reproduction in polychaetes. Oceanography and Marine Biology: an Annual Review 30, 443-481. 
Botsford, L.W., Moloney, C.L., Hastings, A., Largier, J.L., Powell, T.M., Higgins, K., Quinn, J.F., 1994. The influence of spatially and temporally varying oceanographic conditions on meroplanktonic metapopulations. Deep Sea Research II 41, 107-145.

Botsford, L.W., 2001. Physical influences on recruitment to California current invertebrate populations on multiple scales. ICES Journal of Marine Science 58, 1081-1091.

Botsford, L.W., Hastings, A., Gaines, S.D., 2001. Dependence of sustainability on the configuration of marine reserves and larval dispersal distance. Ecology Letters 4, 144-150.

Bradbury, I.R., Snelgrove P.V.R., 2001. Contrasting larval transport in demersal fish and benthic invertebrates: the roles of behaviour and advective processes in determining spatial pattern. Canadian Journal of Fisheries and Aquatic Sciences 58, 811-823.

Byers, J., Pringle, J., 2006. Going against the flow: retention, range limits and invasions in advective environments. Marine Ecology Progress Series 313, 27-41.

Caley, M., Carr, M., Hixon, M.A., Hughes, T.P., Jones, G.P., Menge, B.A., 1996. Recruitment and the local dynamics of open marine populations. Annual Review of Ecology and Systematics 27, 477-500.

Cazaux, C., 1970. Recherches sur l'écologie et le développement larvaire des polychètes de la région d'Arcachon. Thèse d'état, Université de Bordeaux.

Cowen, R.K., Lwiza, K.M.M., Sponaugle, S., Paris, C., Olson, D., 2000. Connectivity of marine populations: open or closed? Science 287, 857-859.

Cowen, R.K., Sponaugle, S., 2009. Larval dispersal and marine population connectivity. Annual Review of Marine Science 1, 443-446.

Cunningham, P.N., Hawkins, S.J., Jones, H.D., Burrows, M.T., 1984. The biogeography and ecology of Sabellaria alveolata. Nature Conservancy Council CSD report, $\mathrm{n}^{\circ} 535$, Peterborough. 
Dekshenieks, M.M., Hofmann, E.E., Klinck, J.M., Powell, E.N., 1997. A modelling study of the effects of size- and depth-dependent predation on larval survival. Journal of Plankton Research 19, 15831598.

Delhez, E., Damm, P., De Goede, E. , de Kok, J., Dumas, F., Gerritsen, H., Jones, J., Ozer, J., Polhmann, T., Rash, P., Skogen, M., Proctor, R., 2004. Variability of shelf seas hydrodynamic models : lessons from NOMADS2. Journal of Marine Systems 45, 39-53.

Dubois, S., 2003. Ecologie des formations récifales à Sabellaria alveolata (L.): valeur fonctionnelle et patrimoniale. Thèse de doctorat, Muséum National d'Histoire Naturelle, Paris.

Dubois, S., Retière, C., Olivier, F., 2002. Biodiversity associated with Sabellaria alveolata (Polychaeta: Sabellariidae) reefs: effects of human disturbances. Journal of the Marine Biological Association of the United Kingdom 82, 817-826.

Dubois, S., Commito, J.A., Olivier, F., Retière, C., 2006. Effects of epibionts on Sabellaria alveolata (L.) biogenic reefs and their associated fauna in the Bay of Mont Saint-Michel. Estuarine, Coastal and Shelf Science 68, 635-646.

Dubois, S., Comtet, T., Retière, C., Thiébaut, E., 2007. Distribution and retention of Sabellaria alveolata larvae (Polychaeta: Sabellariidae) in the Bay of Mont-Saint-Michel, France. Marine Ecology Progress Series 346, 243-254.

Dunstan, P.K., Bax, N.J., 2007. How far can marine species go? Influence of population biology and larval movement on future range limits. Marine Ecology Progress Series 344, 15-28.

Eckman, J.E., 1996. Closing the larval loop: linking larval ecology to the population dynamics of marine benthic invertebrates. Journal of Experimental Marine Biology and Ecology 200 (1/2), 207-237.

Ellien, C., Thiébaut, E., Dumas, F., Salomon, J.C., Nival, P., 2004. A modelling study of the 
respective role of hydrodynamic processes and larval mortality on larval dispersal and recruitment of benthic invertebrates: example of Pectinaria koreni (Annelida: Polychaeta) in the Bay of Seine (English Channel). Journal of Plankton Research 26, 117-132.

Farcy, S., 2003. Analyse de la structure génétique des populations de Sabellaria alveolata (L.) dans la baie du Mont-Saint-Michel à l'aide de marqueurs microsatellites. D.E.S.S. Gestion de la biodiversité, Université Pierre et Marie Curie, Paris.

Gaines, S.D., Gaylord, B., Largier, J.L., 2003. Avoiding current oversights in marine reserve design. Ecological Applications 13, S32-S46.

Gerber, L.R., Botsford, L.W., Hastings, A., Possingham, H.P., Gaines, S.D., Palumbi, S.R., Andelman, S., 2003. Population models for marine reserve design: a retrospective and prospective synthesis. Ecological Applications 13, S47-S64.

Gilg, M.R., Hilbish, T.J., 2003. The geography of marine larval dispersal : coupling genetics with fine-scale physical oceanography. Ecology 84, 2989-2998.

Gruet, Y., 1982. Recherche sur l'écologie des récifs d'hermelles édifiés par l'annélide polychète Sabellaria alveolata (Linné). Thèse d'état. Université de Nantes.

Gruet, Y., 1986. Spatio-temporal changes of sabellarian reefs built by the sedentary polychaete Sabellaria alveolata (Linné). Marine Ecology 7, 303-319.

Guizien, K., Brochier, T., Duchêne, J., Koh, B., Marsaleix, P., 2006. Dispersal of Owenia fusiformis larvae by wind-driven currents: turbulence, swimming behaviour and mortality in a threedimensional stochastic model. Marine Ecology Progress Series 311, 47-66.

Hastings, A., Botsford, L.W., 2006. Persistence of spatial populations depends on returning home. Proceedings of the National Academy of Sciences of the USA 103, 6067-6072. 
Hastings, A., Byers, J.E., Crooks, J.A., Cuddington, K., Jones, C.G., Lambrinos, J.G., Talley, T.S., Wilson, W.G., 2007. Ecosystem engineering in space and time. Ecology Letters 10, 153-164.

Holt, T.J., Rees, E.I., Hawkins, S.J., Seed, R., 1998. Biogenic reefs. An overview of dynamic and sensitivity characteristics for conservation management of marine SACs. Scottish Association for Marine Science, UK Marine SACs Project, Liverpool.

Jolly, M.T., Guyard, P., Ellien, C., Gentil, F., Viard, F., Thiébaut, E., Jollivet, D., 2009. Population genetics and hydrodynamic modelling of larval dispersal dissociate contemporary patterns of connectivity from historical expansion into European shelf seas in the polychaete Pectinaria koreni (Malmgren). Limnology and Oceanography (in press).

Jones, C., Lawton, J., Shachak, M., 1997. Positive and negative effects of organisms as physical ecosystem engineers. Ecology 78 (78), 1946-1957.

Jones, M.B., Epifanio, C.E., 1995. Settlement of brachyuran megalopae in Delaware Bay: a time series analysis. Marine Ecology Progress Series 125, 67-76.

Kinlan, B.P., Gaines, S.D., Lester, S.E., 2005. Propagule dispersal and the scales of marine community process. Diversity and Distribution 11, 139-148.

Kritzer, J.P., Sale, P.F., 2003. Metapopulation ecology in the sea : from Levin's model to marine ecology and fisheries science. Fish and Fisheries 4, 1-10.

Lagadeuc, Y., 1992. Transport larvaire en Manche. Exemple de Pectinaria koreni (Malmgren), annélide polychète, en baie de Seine. Oceanologica Acta, 15, 109-118.

Largier, J., 2003. Considerations in estimating larval dispersal distances from oceanographic data. Ecological Applications, 13, S71-S89.

Lazure, P., Dumas, F., 2008. An external-internal mode coupling for a 3D hydrodynamical model 
for applications at regional scale (MARS). Advances in Water Resources. 31 (2), 233-250.

Lazure, P., Jegou, A., 1998. 3D modelling of seasonal evolution of Loire and Gironde plumes on Biscay Bay continental shelf. Oceanologica Acta 21, 165-177.

Lehane, C., Davenport, J., 2006. A 15-month study of zooplankton ingestion by farmed mussels (Mytilus edulis) in Bantry Bay, Southwest Ireland. Estuarine, Coastal and Shelf Science 67, 645-652.

Levin, L., 2006. Recent progress in understanding larval dispersal: new directions and digressions. Integrative and Comparative Biology 46 (3), 282-297.

Luyten, P.J., Deleersnijder, E., Ozer, J., Ruddick, K.G., 1996. Presentation of a family of turbulence closure models for stratified shallow water flows and preliminary application to the Rhine outflow region. Continental Shelf Research 16, 101-30.

McCarthy, D., Young, C., Emson, R., 2003. Influence of wave-induced disturbance on seasonal spawning patterns in the sabellariid polychaete Phragmatopoma lapidosa. Marine Ecology Progress Series 256, 123-133.

Ménesguen, A., Gohin, F., 2006. Observation and modelling of natural retention structures in the English Channel. Journal of Marine Systems 63, 244-256.

Miller, T.J., 2007. Contribution of individual-based coupled physical-biological models to understanding recruitment in marine fish populations. Marine Ecology Progress Series 347: 127-138.

North, E.W., Schlag, Z., Hood, R.R., Li, M., Zhong, L., Gross, T., Kennedy, V.S., 2008. Vertical swimming behaviour influences the dispersal of simulated oyster larvae in a coupled particle-tracking and hydrodynamic model of Chesapeake Bay. Marine Ecology Progress Series 359, 99-115.

O'Connor, M., Bruno, J., Gaines, S., Halpern, B., Lester, S., Kinlan, B., Weiss, J., 2007. Temperature control of larval dispersal and the implications for marine ecology, evolution, and 
conservation. Proceedings of the National Academy of Sciences of the USA 104, 1266-1271.

Olive, P.J.W., 1992. The adaptative significance of seasonal reproduction in marine invertebrates: the importance of distinguishing between models. Invertebrate Reproduction and Development 22, 165 174.

Orbi, A., Salomon, J.C., 1988. Tidal dynamics in the vicinity of the Channel Islands. Oceanologica Acta 11(1), p. 55-64.

Pawlick, J.R., 1988. Larval settlement and metamorphosis of two gregarious sabellariid polychaetes: Sabellaria alveolata compared with Phragmatopoma californica. Journal of the Marine Biological Association of the United Kingdom 68, 101-124.

Pawlick, J.R., Butman, C.A., 1993. Settlement of a marine tube worm as a function of current velocity: interacting effects of hydrodynamics and behaviour. Limnology and Oceanography 38(8), 17301740.

Pechenik, J., Rittschof, D., Schmidt, A., 1993. Influence of delayed metamorphosis on survival and growth of juvenile barnacles Balanus amphitrite. Marine Biology 115, 287-294.

Pedersen, O., Nilssen, E., Jørgensen, L.L., Slagstad, D., 2006. Advection of the red king crab larvae on the coast of north Norway - a Lagrangian model study. Fisheries Research 79, 325-336.

Pingree, R.D., Mardell, D.T., Maddock, L., 1985. Tidal mixing in the Channel Isles region derived from the results of remote sensing and measurements at sea. Estuarine, Coastal and Shelf Science 20, 118.

Plus, M., Dumas, F., Stanisière, J.Y., Maurer, D., 2009. Hydrodynamic characterization of the Arcachon Bay, using model-derived descriptors. Continental Shelf Research. doi:10.1016/j.csr.2008.12.016 
Populus, J., Laurentin, A., Rollet, C., Vasquez, M., Guillaumont, B., Bonnot-Courtois, C., 2004. Surveying coastal zone topography with airborne remote sensing for benthos mapping. Journal of Remote Sensing and Photogrammetry 3, 105-117.

Rumrill, S., 1990. Natural mortality of marine invertebrate larvae. Ophelia 32, 163-198.

Salomon, J.C., Breton, M., 1993. An atlas of long-tem currents in the Channel. Oceanologica Acta 16, 439-448.

Salomon, J.C., Garreau, P., Breton, M., 1996. The Lagrangian barycentric method to compute 2d and 3d long term dispersion in tidal environments. In Mixing Processes in Estuaries and Coastal Seas. Pattiaratchi, C. (ed.). American Geophysical Union, Washington DC, vol. 50 pp. 59-76.

Schwiderski, E.W., 1983. Atlas of ocean tidal charts and maps. Marine Geodesy 6, 219-265.

Sentchev, A., Forget, P., Barbin, Y., 2009. Residual and tidal circulation revealed by VHF radar surface current measurements in the southern Channel Isles region (English Channel). Estuarine, Coastal and Shelf Science 82, 180-192.

Starr, M., Himmelman, J.H., Therriault, J.-C., 1990. Direct coupling of marine invertebrate spawning with phytoplankton blooms. Science 247, 1071-1074.

Treml, E., Halpin, P., Urban, D., Pratson, L., 2008. Modeling population connectivity by ocean currents, a graph-theoretic approach for marine conservation. Landscape Ecology 23, 19-36.

Troost, K., Kamermans, P., Wolff, W.J., 2008. Larviphagy in native bivalves and an introduced oyster. Journal of Sea Research 60, 157-163.

Verdier-Bonnet, C., Carlotti, F., Rey, C., Bhaud, M., 1997. A model of larval dispersion coupling wind-driven currents and vertical larval behaviour: application to the recruitment of the annelid Owenia fusiformis in Banyuls bay, France. Marine Ecology Progress Series 160, 217-231. 
Vorberg, R., 1995. On the decrease of sabellarian reefs along the German North Sea coast. Publications du Service géologique de Luxembourg 24, 87-93.

Wilson, D.P., 1968a. The settlement behaviour of the larvae of Sabellaria alveolata (L.). Journal of the Marine Biological Association of the United Kingdom 48, 387-435.

Wilson, D.P., 1968b. Some aspects of the development of eggs and larvae of Sabellaria alveolata (L.). Journal of the Marine Biological Association of the United Kingdom 48, 367-386..

Wilson, D.P., 1970. Additional observations on larval growth and settlement of Sabellaria alveolata. Journal of the Marine Biological Association of the United Kingdom 50, 1-31.

Wilson, D.P., 1971. Sabellaria colonies at Duckpool, North Cornwall, 1961-1970. Journal of the Marine Biological Association of the United Kingdom 51, 509-580.

Wing, S.R., Largier, J.L., Botsford, L.W., Quinn, J.F., 1995. Settlement and transport of benthic invertebrates in an intermittent upwelling region. Limnology Oceanography 40, 316-329.

Woodson, C.B., McManus, M.A., 2007. Foraging behaviour can influence dispersal of marine organisms. Limnology and Oceanography 52, 2701-2709.

Xie, H.Q., Lazure P., Gentien P., 2007. Small scale retentive structures and Dinophysis. Journal of Marine Systems 64 (1-4), 173-188. 
Figure

Fig. 1. Location of the Bay of Mont-Saint-Michel (BMSM) and of the two Sabellaria alveolata reefs. SA: Sainte-Anne reef. $\mathrm{CH}$ : Champeaux reef.

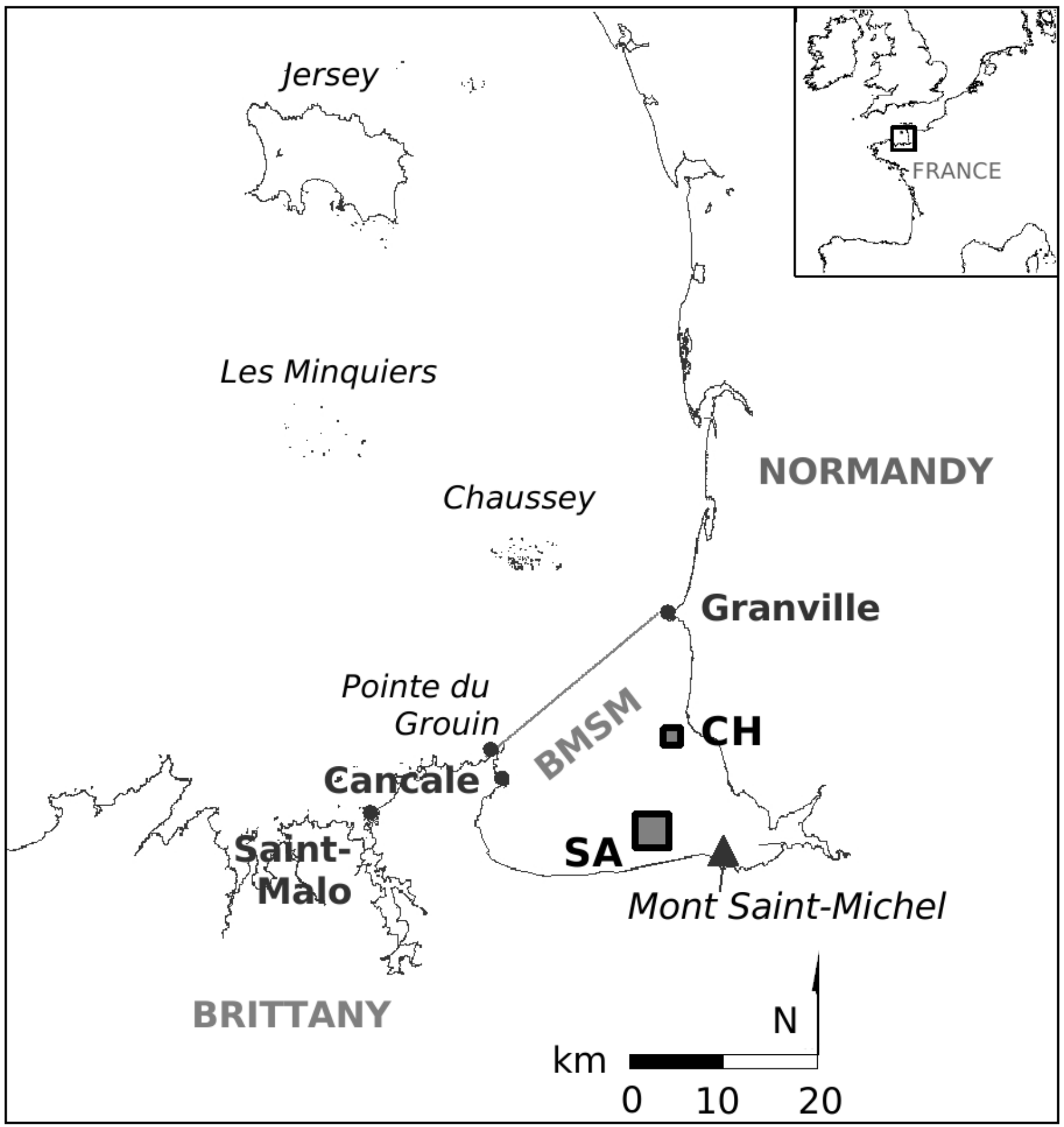


Fig. 2. Simulated depth-averaged residual Lagrangian velocity fields in the Gulf of Saint-Malo for average tide conditions and no wind forcing (A), a constant SW-wind forcing of $11 \mathrm{~m} \mathrm{~s}^{-1}$ (B), and a constant NE-wind forcing of $11 \mathrm{~m} \mathrm{~s}^{-1}(\mathrm{C})$. Empty arrows indicate the wind orientation. Residual velocities are given in $\mathrm{cm} \mathrm{s}^{-1}$.
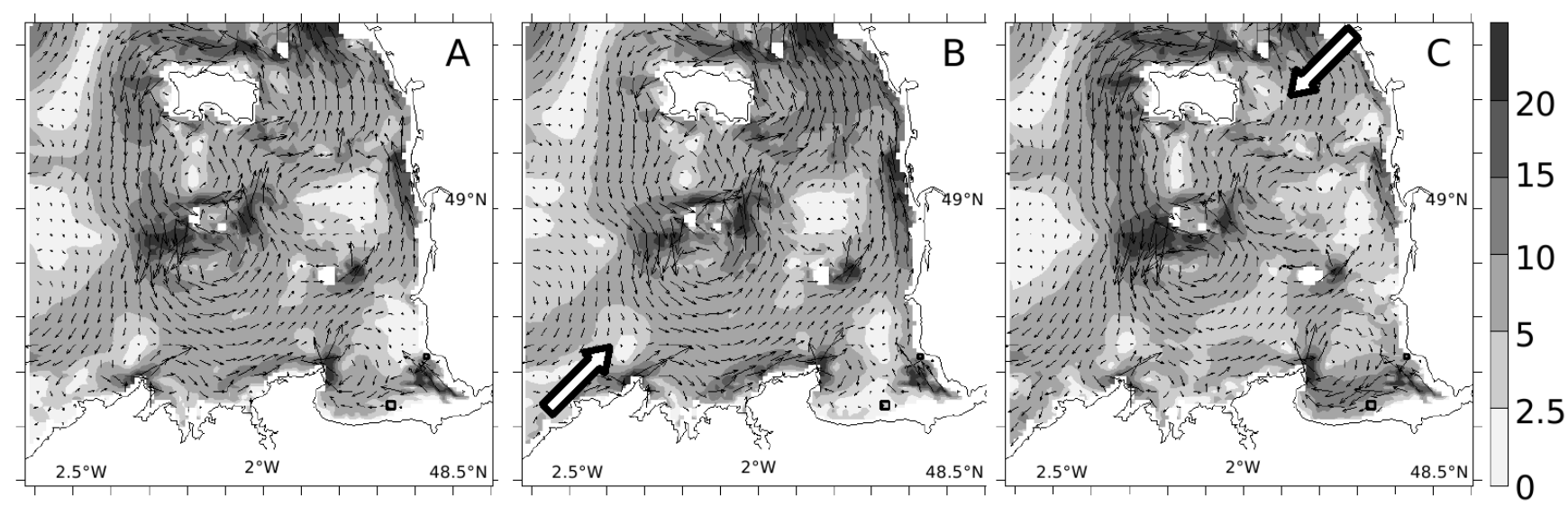
Fig. 3. Predicted larval distributions following a spawning event from Sainte-Anne (A-C) and from Champeaux (D-F) at high tide and in average tide conditions after 3 days (A and D), 3 weeks (B and E), and 6 weeks ( $\mathrm{C}$ and F). The two black squares represent the reefs of Sainte-Anne and Champeaux. No wind forcing is considered. Larval concentrations are given in $10^{4}$ ind $\mathrm{m}^{-2}$. Note that the scales of the larval concentrations differ between the maps.

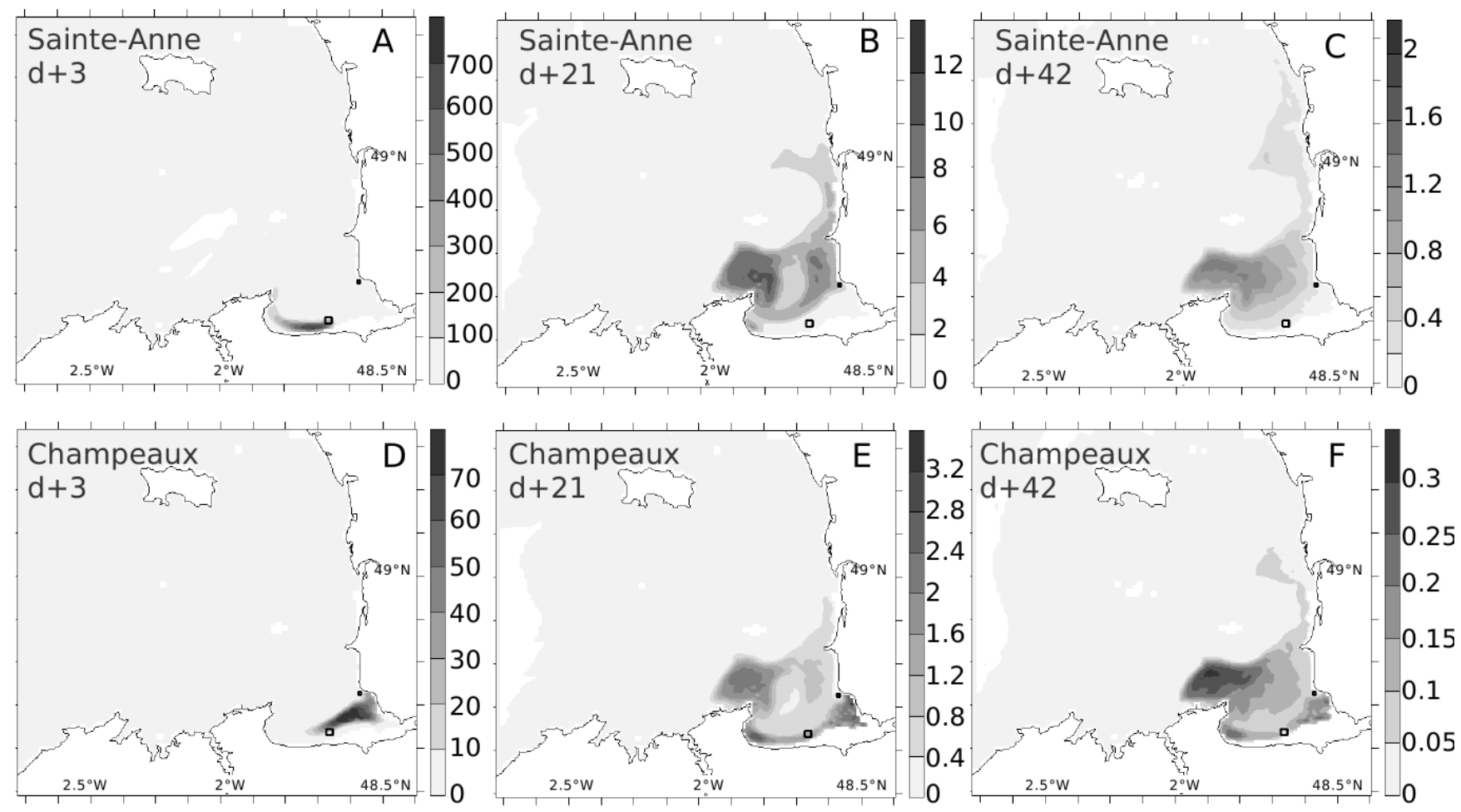


Fig. 4. Variations in the settlement rates of larvae released from the reefs of Sainte-Anne and Champeaux in relation to the larval release duration: 1) instantaneous spawning, 2) continuous and uniform spawning during 1 tidal cycle, 3) semi-continuous and symmetric spawning during 3 tidal cycles, and 4) semi-continuous and symmetric spawning during 5 tidal cycles. Larval dispersal is simulated without wind forcing during 10 weeks.

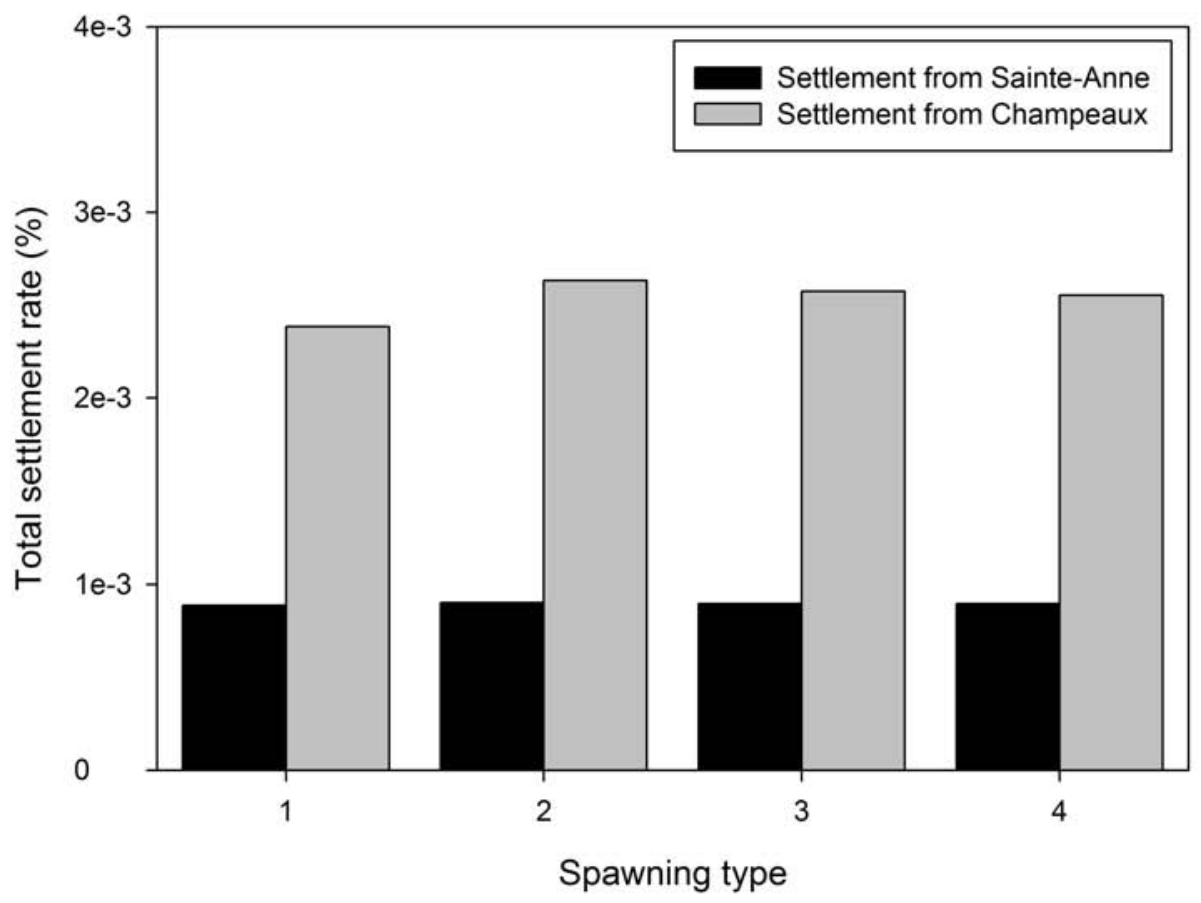


Fig. 5. Variations in retention rates (A), colonization rates (B) and allochthonous settlers' ratio (C) according to the tidal range at spawning for larvae released from the two reefs. Larval releases occur at high tide and dispersal is simulated without wind forcing during 10 weeks.
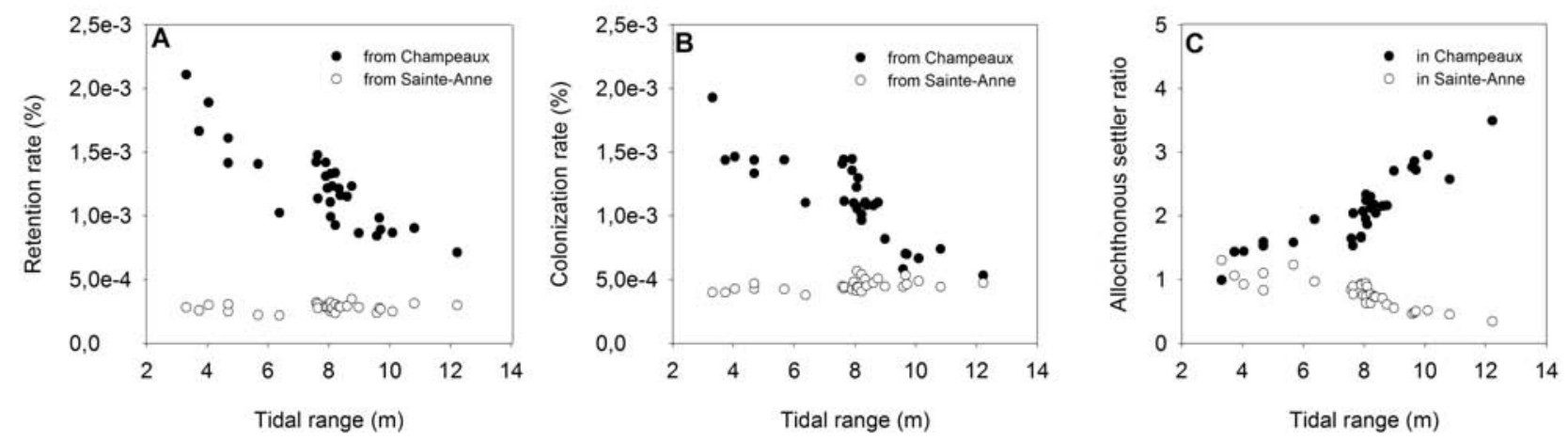
Fig. 6. Predicted distributions of larvae released from Champeaux in conditions of neap tide (A-C) and spring tide (D-F) after 3 days (A and D), 3 weeks (B and E) and 6 weeks(C and F) of dispersal without wind forcing. The two black squares represent the reefs of Sainte-Anne and Champeaux. The larval concentrations are given in $10^{4}$ ind $\mathrm{m}^{-2}$. Note that the scales of the larval concentrations differ between the maps.
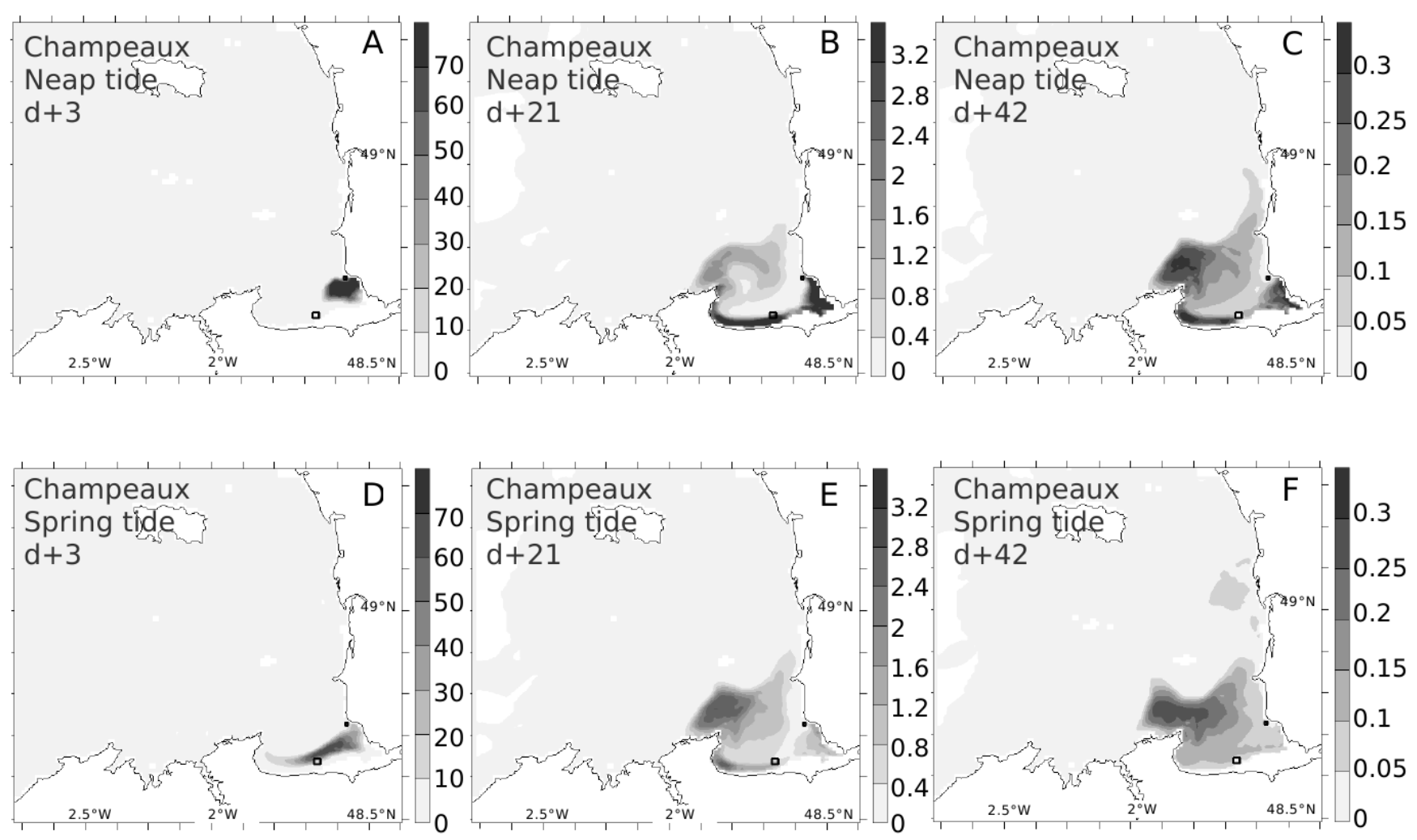
Fig. 7. Seasonal variations in retention and colonization rates for 16 spawning events, from March to October 2002, with and without real wind forcing: retention rate in Champeaux (A); colonization rate from Champeaux to Sainte-Anne (B); retention rate in Sainte-Anne (C); colonization rates from SainteAnne to Champeaux (D). Larval releases occur at high tide in average tide conditions and dispersal is simulated during 10 weeks.
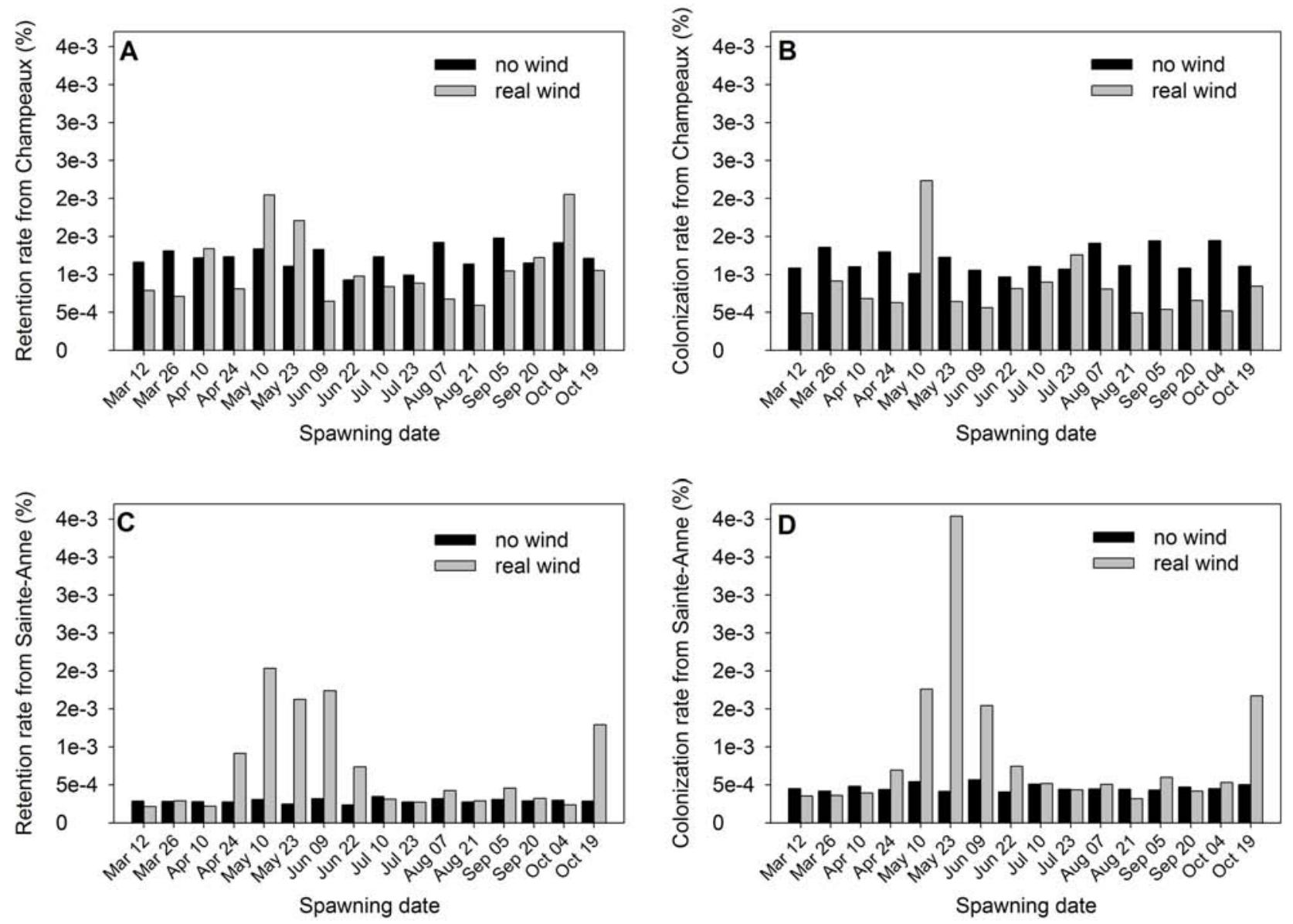
Fig. 8. Examples of predicted distributions of larvae released from Sainte-Anne on 10 May (A-C), 23 May (D-F), 21 August (G-I), and 19 October 2002 (J-L) after 3 weeks (A, D, G, J) and 6 weeks (B, E, $\mathrm{H}, \mathrm{K}$ ) of dispersal with real wind forcing. Larval releases occur at high tide in average tide conditions. The two black squares represent the adult reefs of Sainte-Anne and Champeaux. The larval concentrations are given in $10^{4}$ ind $\mathrm{m}^{-2}$. Note that the scales of the larval concentrations differ between the maps. Progressive vector diagrams (PDV) of the wind forcing in the Gulf of Saint-Malo during larval dispersal are indicated for each spawning event, with West to East transport $\left(10^{3} \mathrm{~km}\right)$ as abscissa and South to North transport $\left(10^{3} \mathrm{~km}\right)$ as ordinate. The gray diamonds indicate the $3^{\text {rd }}$ and the $6^{\text {th }}$ week of dispersal. Wind data provided by Météo France (Arpège model). 

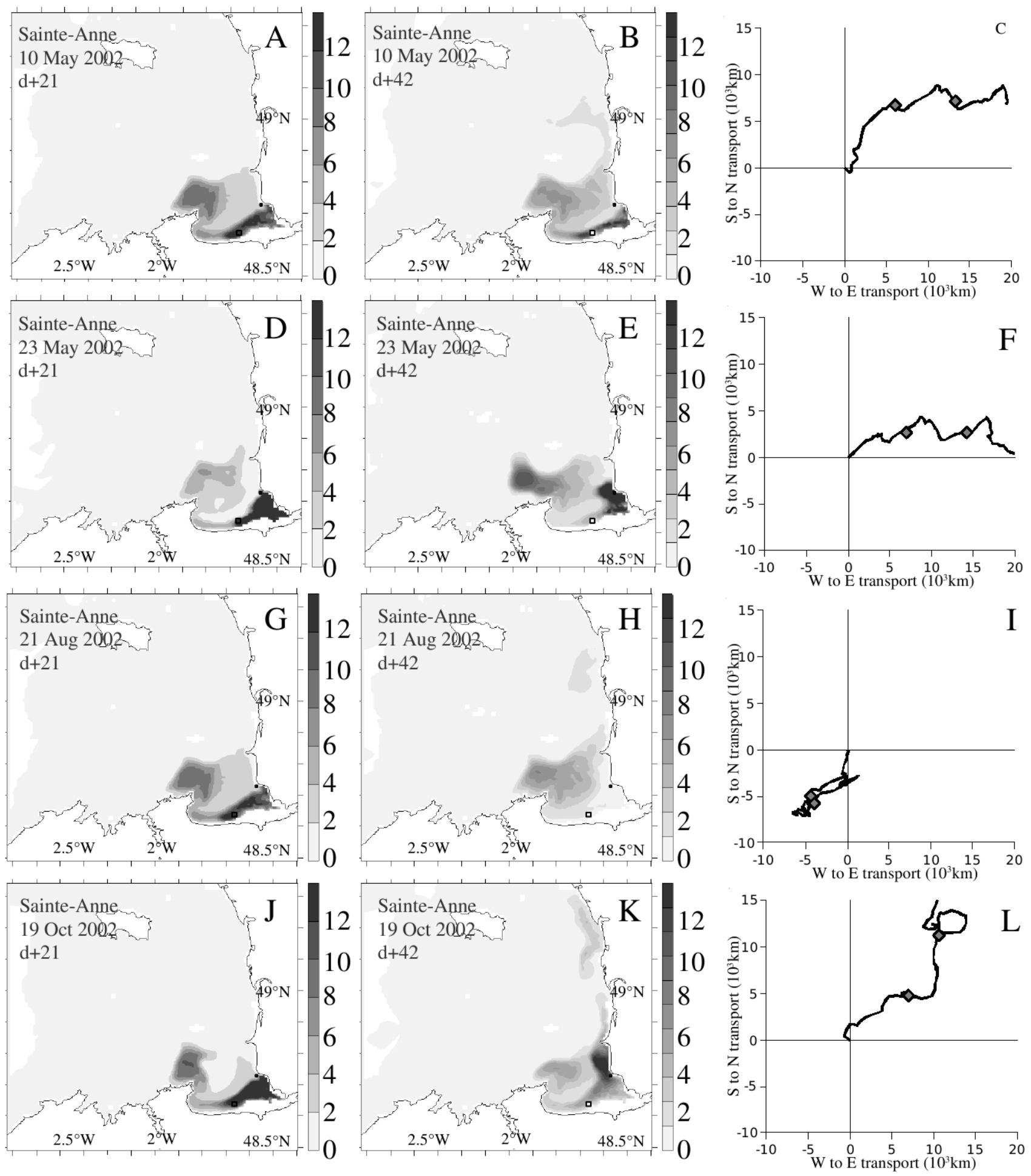
Fig. 9. Intra- and inter-annual variability of the origin and number of settlers for different larval releases between 2000 and 2004. For each year, 7 spawning events are simulated from April to October with a larval release at high tide during average tide conditions. Larval dispersal is simulated under real wind forcing during 10 weeks. Progressive vector diagrams (PVD) of wind forcing in the Gulf of SaintMalo corresponding to the dispersal following a release in May are given for each year, with West to East transport $\left(10^{3} \mathrm{~km}\right)$ as abscissa and South to North transport $\left(10^{3} \mathrm{~km}\right)$ as ordinate. The gray diamonds indicate the $3^{\text {rd }}$ and the $6^{\text {th }}$ week of dispersal. Wind data provided by Météo France (Arpège model).

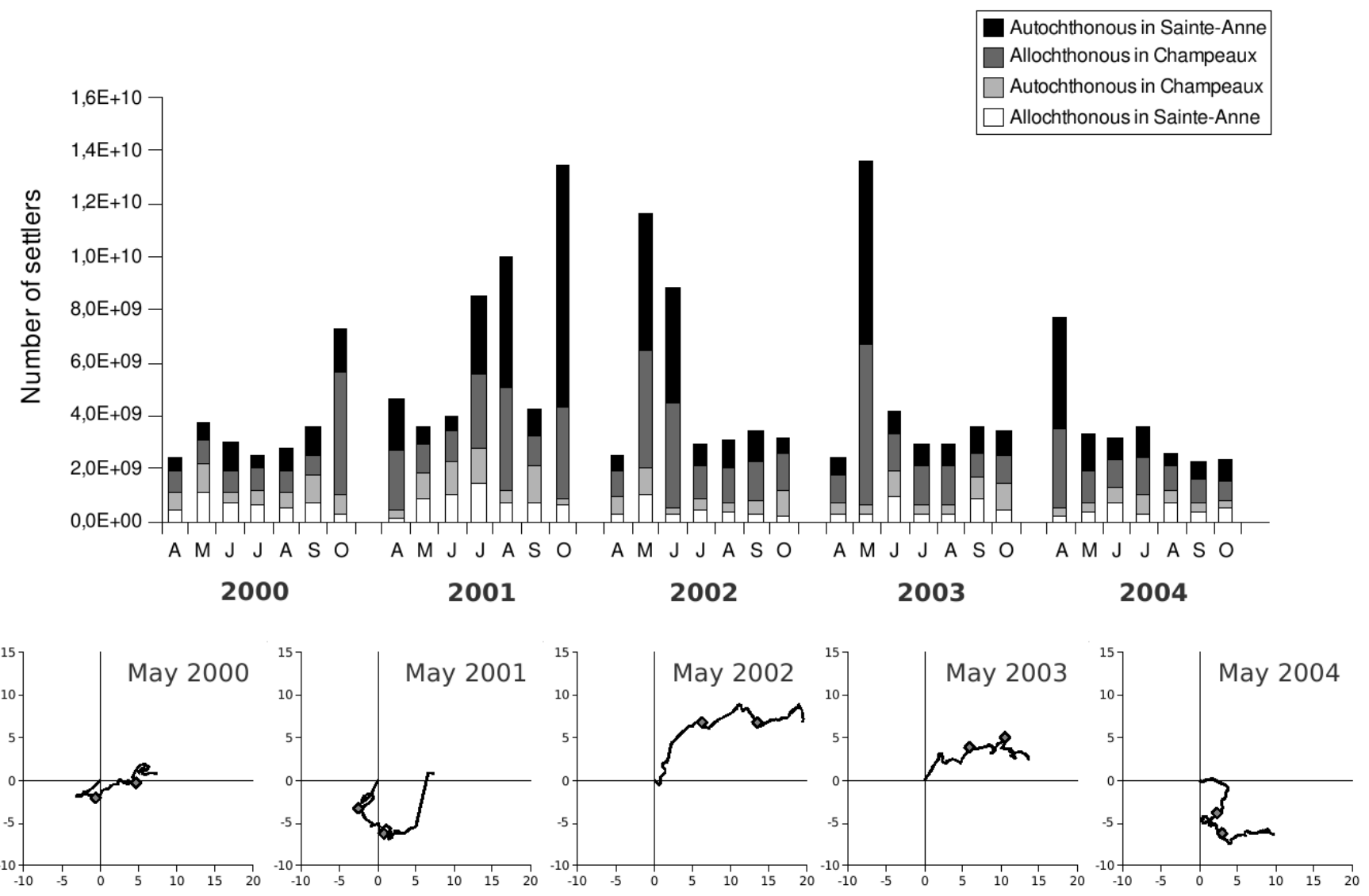


Fig. 10. Temporal evolution of the cumulative numbers of settlers for 4 spawning events from Sainte-Anne on 10 May (A), 23 May (B), 21 August (C) and 19 October 2002 (D), from the beginning of the settlement ( $\mathrm{t}=0 \mathrm{~d}$ after 6 weeks of dispersal) to the end of dispersal $(\mathrm{t}=28 \mathrm{~d}$ after 10 weeks of dispersal). Larvae are released at high tide in average tide conditions and dispersal occured under real wind forcing. Continuous line: autochthonous settlers in Sainte-Anne, dashed line: allochthonous settlers in Champeaux.
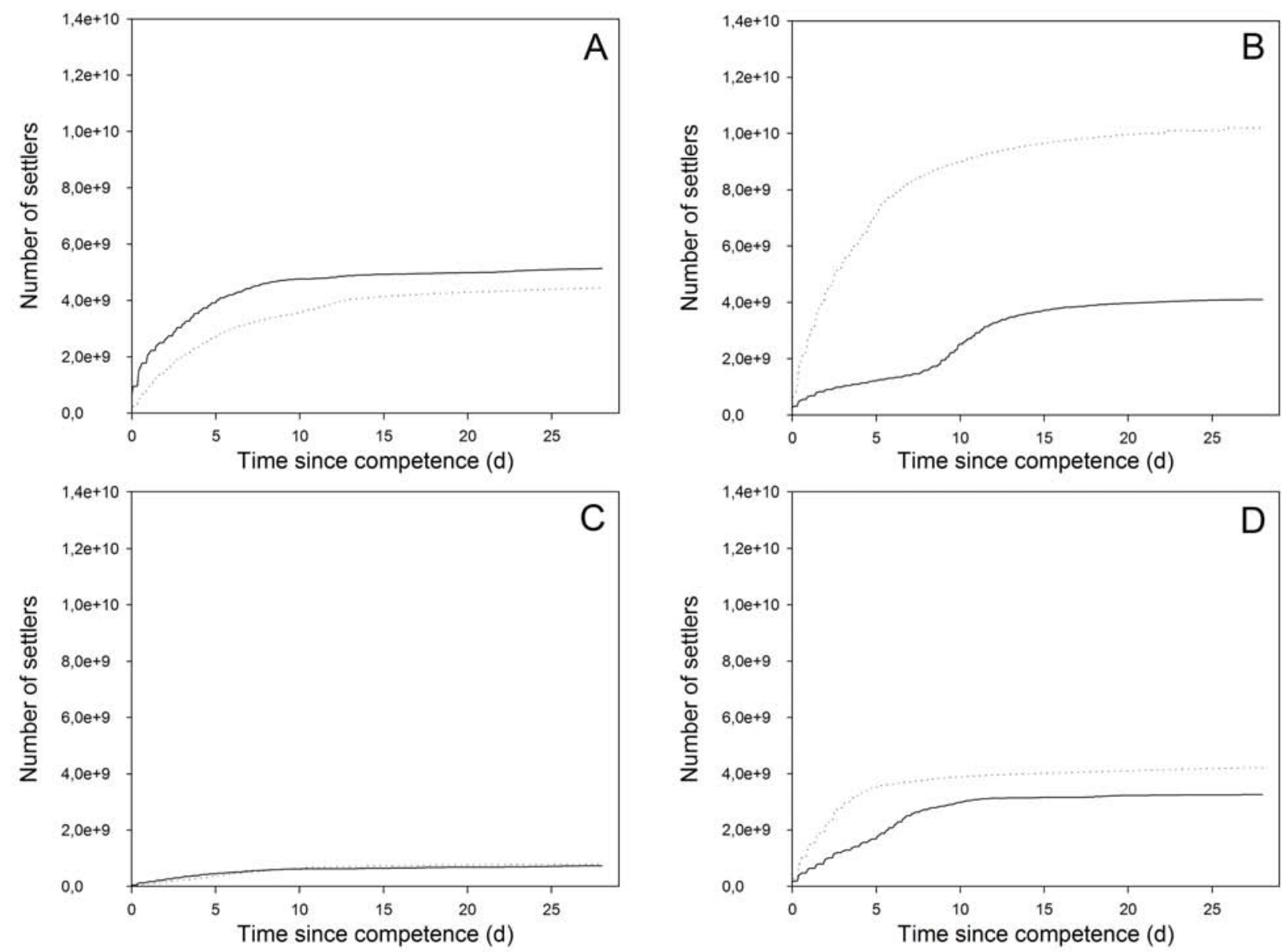
Fig. 11. Variability of the origin and number of settlers for different ages at competence (minimal PDL). Age at competence is given in week. The maximum delay to metamorphosis is fixed at 4 weeks. Larval release is instantaneous at high tide during average tide conditions. Larval dispersal is simulated without wind forcing.

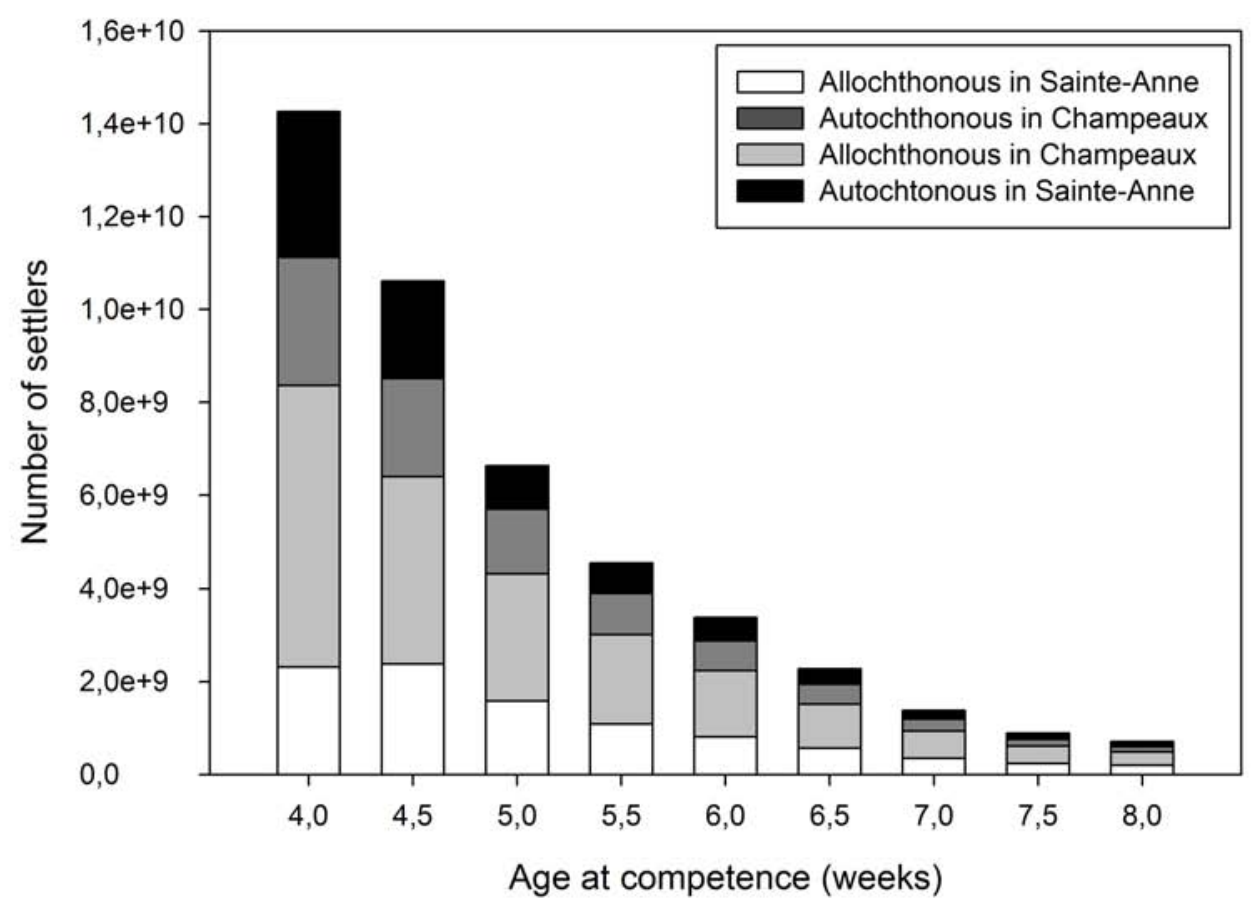


Table 1. Properties of Sabellaria alveolata populations used to calculate the number of released larvae for each spawning event. ${ }^{a}$ Dubois (2003); ${ }^{b}$ Dubois et al. (2002).

\begin{tabular}{|c|c|c|}
\hline & Sainte-Anne Reef & Champeaux Reef \\
\hline Reef area $\left(\mathrm{m}^{2}\right)^{\mathrm{a}}$ & $2.2310^{6}$ & $0.2910^{6}$ \\
\hline \multicolumn{3}{|l|}{ Ball-shaped structures } \\
\hline proportion $(\%)^{\mathrm{a}}$ & 20 & 20 \\
\hline worm density (ind. $\left.\mathrm{m}^{-2}\right)^{\mathrm{b}}$ & 25,000 & 25,000 \\
\hline \multicolumn{3}{|l|}{ Platform structures } \\
\hline proportion $(\%)^{\mathrm{a}}$ & 30 & 60 \\
\hline worm density (ind. $\left.\mathrm{m}^{-2}\right)^{\mathrm{b}}$ & 35,000 & 35,000 \\
\hline \multicolumn{3}{|l|}{ Degraded reef } \\
\hline proportion $(\%)^{\mathrm{a}}$ & 50 & 20 \\
\hline worm density (ind. $\left.\mathrm{m}^{-2}\right)^{\mathrm{b}}$ & 6,500 & 6,500 \\
\hline Adult stock & 4.2. $10^{10}$ & $0.810^{10}$ \\
\hline Sex-ratio $^{a}$ & $1: 1$ & $1: 1$ \\
\hline Mean proportion of mature females $(\%)^{\mathrm{a}}$ & 15 & 15 \\
\hline Mean fecundity ${ }^{a}$ & 100,000 & 100,000 \\
\hline Fertilization rate & 0.8 & 0.8 \\
\hline Number of released larvae & $2.5210^{14}$ & $4.810^{13}$ \\
\hline
\end{tabular}


Table 2. Conditions of the different simulations of Sabellaria alveolata larval dispersal in the Bay of Mont-Saint-Michel.

\begin{tabular}{|c|c|c|c|c|c|c|c|}
\hline \multirow{2}{*}{$\begin{array}{c}\text { Conditions } \\
\text { Year }\end{array}$} & \multicolumn{5}{|c|}{ Simulations } & \multirow[b]{2}{*}{$\begin{array}{l}2000 \text { to } \\
2004\end{array}$} & \multirow[b]{2}{*}{2002} \\
\hline & 2002 & 2002 & 2002 & 2002 & 2002 & & \\
\hline Spawning period & June & $\begin{array}{l}\text { March to } \\
\text { October }\end{array}$ & $\begin{array}{l}\text { April to } \\
\text { October }\end{array}$ & $\begin{array}{l}\text { April to } \\
\text { October }\end{array}$ & $\begin{array}{l}\text { March to } \\
\text { October }\end{array}$ & $\begin{array}{l}\text { April to } \\
\text { October }\end{array}$ & June \\
\hline $\begin{array}{c}\text { Lunar tidal conditions at } \\
\text { larval release }\end{array}$ & Average tide & $\begin{array}{l}\text { Average } \\
\text { tide }\end{array}$ & $\begin{array}{l}\text { Neap } \\
\text { tide }\end{array}$ & $\begin{array}{l}\text { Spring } \\
\text { tide }\end{array}$ & $\begin{array}{l}\text { Average } \\
\text { tide }\end{array}$ & $\begin{array}{l}\text { Average } \\
\text { tide }\end{array}$ & $\begin{array}{l}\text { Average } \\
\text { tide }\end{array}$ \\
\hline Larval release type & $\begin{array}{l}\text { Instantaneous } \\
\text { or continuous } \\
\text { during } 1,3 \text {, or } \\
5 \text { tidal cycles }\end{array}$ & $\begin{array}{l}\text { Instanta- } \\
\text { neous at } \\
\text { high tide }\end{array}$ & $\begin{array}{l}\text { Instanta- } \\
\text { neous at } \\
\text { high tide }\end{array}$ & $\begin{array}{l}\text { Instanta- } \\
\text { neous at } \\
\text { high tide }\end{array}$ & $\begin{array}{l}\text { Instanta- } \\
\text { neous at } \\
\text { high tide }\end{array}$ & $\begin{array}{l}\text { Instanta- } \\
\text { neous at } \\
\text { high tide }\end{array}$ & $\begin{array}{c}\text { Instanta } \\
\text {-neous } \\
\text { at high } \\
\text { tide }\end{array}$ \\
\hline Wind forcing & No & No & No & No & $\begin{array}{l}\text { Real } \\
\text { wind }\end{array}$ & $\begin{array}{l}\text { Real } \\
\text { wind }\end{array}$ & No \\
\hline Minimal PLD & 6 weeks & 6 weeks & 6 weeks & 6 weeks & 6 weeks & 6 weeks & $\begin{array}{l}\text { from } 4 \\
\text { to } 8 \\
\text { weeks }\end{array}$ \\
\hline Simulation frequency & $\begin{array}{c}1 \text { per release } \\
\text { type }\end{array}$ & $\begin{array}{l}2 \text { per } \\
\text { month }\end{array}$ & $\begin{array}{l}1 \text { per } \\
\text { month }\end{array}$ & $\begin{array}{l}1 \text { per } \\
\text { month }\end{array}$ & $\begin{array}{l}2 \text { per } \\
\text { month }\end{array}$ & $\begin{array}{l}1 \text { per } \\
\text { month }\end{array}$ & $\begin{array}{c}1 \text { per } \\
\text { minimal } \\
\text { PLD }\end{array}$ \\
\hline Number of simulations & 4 & 16 & 7 & 7 & 16 & 28 & 9 \\
\hline
\end{tabular}


Appendix - Table 1. Values of the parameters used in the mathematical formulation of complex larval release. $\mathrm{HT}=$ High tide.

45

\begin{tabular}{|c|c|c|c|c|}
\hline Spawning type & $\Delta t$ & $t_{b}$ & $t_{e}$ & $p$ \\
\hline $\begin{array}{c}\text { Uniform continuous spawning } \\
\text { over } 1 \text { tidal cycle }\end{array}$ & $4 \mathrm{~h}$ & HT- $2 \mathrm{~h}$ & $\mathrm{HT}+2 \mathrm{~h}$ & $100 \%$ \\
\hline $\begin{array}{c}\text { Symmetric semi-continuous } \\
\text { spawning } \\
\text { over } 3 \text { tidal cycles }\end{array}$ & $4 \mathrm{~h}$ & $\begin{array}{l}\text { HT- } 14 \mathrm{~h} 20 \\
\text { HT- } 2 \mathrm{~h} \\
\text { HT }+10 \mathrm{~h} 20\end{array}$ & $\begin{array}{l}\mathrm{HT}+10 \mathrm{~h} 20 \\
\mathrm{HT}+2 \mathrm{~h} \\
\mathrm{HT}+14 \mathrm{~h} 20\end{array}$ & $\begin{array}{l}25 \% \\
50 \% \\
25 \%\end{array}$ \\
\hline $\begin{array}{l}\text { Symmetric semi-continuous } \\
\text { spawning } \\
\text { over } 5 \text { tidal cycles }\end{array}$ & $4 \mathrm{~h}$ & $\begin{array}{c}\text { HT-26h40 } \\
\text { HT-14h20 } \\
\text { HT-2h } \\
\text { HT }+10 \mathrm{~h} 20 \\
\text { HT }+22 \mathrm{~h} 40\end{array}$ & $\begin{array}{c}\text { HT- } 22 \mathrm{~h} 40 \\
\text { HT- } 10 \mathrm{~h} 20 \\
\mathrm{HT}+2 \mathrm{~h} \\
\mathrm{HT}+14 \mathrm{~h} 20 \\
\mathrm{HT}+26 \mathrm{~h} 40\end{array}$ & $\begin{array}{l}10 \% \\
20 \% \\
40 \% \\
20 \% \\
10 \% \\
\end{array}$ \\
\hline
\end{tabular}

